\title{
Geneza idei epistemicznych układów odniesienia i ich odmiany
}

\section{Uwagi wstępne}

Ogólnie rzecz biorąc, epistemiczny układ odniesienia (EUO) to najbardziej elementarne założenia dotyczące tego, jak należy uprawiać naukę i jak tego robić nie należy.

Celem niniejszego tekstu jest syntetyczne przedstawienie genezy epistemicznych układów odniesienia oraz omówienie odmian owych układów. Idee te rozproszone są w różnych tekstach Zielonogórskiej Grupy Lokalnej „Nauka a Religia”, stąd pomysł na ich jednolite opracowanie.

Tekst ten, nie licząc niniejszego wprowadzenia, składa się z dwóch paragrafów i uwag końcowych. Obydwa paragrafy obszernie korzystają z osiągnięć ZGL „Nauka a Religia”. Mam tu na myśli przede wszystkim Serwis Filozoficzny „Nauka a Religia”, czasopismo internetowe Filozoficzne Aspekty Genezy, serię książkową Biblioteka Filozoficznych Aspektów Genezy oraz liczne prace członków ZGL publikowane w innych czasopismach i seriach książkowych.

W paragrafie drugim (Geneza pojęcia i koncepcji EUO) przedstawiam, skąd wzięła się nazwa „epistemiczny układ odniesienia”. Wskazuję też na koszty epistemiczne akceptacji idei EUO i pokazuję, że idea ta jest już dość powszechnie rozpoznawalna.

Dr hab. Krzysztof J. KiLIAN, PRof. UZ — Uniwersytet Zielonogórski, e-mail: kiliankrzysztof @yahoo.pl.

(C) Copyright by Krzysztof J. Kilian \& Filozoficzne Aspekty Genezy. 
Trzeci paragraf (EUO - definicja, odmiany i ich twarde jądra) przedstawia definicje EUO wraz z ich omówieniem. W omówieniu tym podkreślam, że założenia, na których bazują EUO, są naukowo nieuzasadnialne. Wyjaśniam również, dlaczego tak się dzieje. Odnoszę się tam też do próby metanaukowego uzasadnienia owych założeń. Odmiany EUO: naturalizm, nadnaturalizm oraz artyficjalizm charakteryzowane są poprzez wskazanie na takie metafizyczne tezy, nazywane „twardymi jądrami”, z których ich zwolennicy nigdy nie zrezygnują, bowiem ich porzucenie byłoby tożsame $\mathrm{z}$ zanegowaniem podstawowych założeń, na których bazują EUO.

Omówienie odmian EUO stwarza również sposobność do kilku historycznych uwag, dotyczących przede wszystkim naturalizmu metodologicznego. Wskazuję tam na: jego trzy podstawowe źródła; genezę nazwy „naturalizm metodologiczny"; rolę Karola Darwina i nauk o życiu w ukształtowaniu się podstawowego wymogu tego naturalizmu. Te historyczne uwagi pozwalają również na omówienie kilku nieporozumień, łączonych dość powszechnie z innymi omawianymi tu EUO.

\section{Geneza pojęcia i koncepcji EUO}

Nazwa „epistemiczny układ odniesienia” wprowadzona została przez Kazimierza Jodkowskiego 1 grudnia 2004 roku. ${ }^{1}$ Sam pomysł pojawił się w trakcie

\footnotetext{
${ }^{1}$ Miało to miejsce na konferencji „Filozoficzne i naukowo-przyrodnicze elementy obrazu świata”, Uniwersytet Kardynała Stefana Wyszyńskiego, referat „Epistemiczne układy odniesienia i «warunek Jodkowskiego»” (por. Kazimierz JodKowskI, „Epistemiczne układy odniesienia i «warunek Jodkowskiego»”, w: Anna Latawiec i Grzegorz BugajaK (red.), Filozoficzne i naukowoprzyrodnicze elementy obrazu świata 7 , Wydawnictwo Uniwersytetu Kardynała Stefana Wyszyńskiego, Warszawa 2008, s. 115 [108-123], www.nauka-a-religia.uz.zgora.pl/images/Inne.teks ty/Jodkowski_Epistemiczne.uklady.odniesienia.i.warunek.Jodkowskiego.pdf [16.02.2018]; Kazimierz JoDKowsKi, „Uczony w ciemnym budynku. Na marginesie metafory Elżbiety Kałuszyńskiej”, w: Józef Dębowski i Ewa StarzyńsKa-Kościuszko (red.), Nauka. Racjonalność. Realizm. Między filozofią przyrody a filozofią nauki i socjologią wiedzy, Instytut Filozofii Uniwersytetu Warmińsko-Mazurskiego w Olsztynie, Olsztyn 2013, s. 58 [55-67], www.nauka-a-religia.uz.zgora .pl/images/Przedruki/Jodkowski_Uczony.w.ciemnym.budynku.pdf [16.02.2018]; Zenon E. RosKAL, „Eksperyment MacDougalla w epistemicznym układzie odniesienia naturalizmu”, w: Piotr Bylica, Krzysztof J. Kilian, Robert Piotrowski i Dariusz SAgan (red.), Filozofia - nauka - religia. Księga jubileuszowa dedykowana Profesorowi Kazimierzowi Jodkowskiemu z okazji 40lecia pracy naukowej, Oficyna Wydawnicza Uniwersytetu Zielonogórskiego, Zielona Góra 2015, s. 166 przyp. 6 [165-172], www.nauka-a-religia.uz.zgora.pl/images/Przedruki/Roskal_Ekspery ment.MacDougalla.pdf [06.02.2018]).
} 
jego analiz sporu ewolucjonizmu z kreacjonizmem, podczas badania stanowisk kreacjonistycznych, w ramach których

stałe dopasowywanie danych naukowych do tego, co mówi Pismo Święte, zwłaszcza kilkanaście pierwszych rozdziałów, wprost rzucało się w oczy. ${ }^{2}$

Kolejnym etapem w rozwoju tego podejścia było dostrzeżenie, że współczesna nauka również ma swoją „świętą księgę”, której treść jest powszechnie akceptowana. Jednakże sama „księga” widoczna jest dopiero wtedy, gdy działania uczonych zestawi się z tym, co robią kreacjoniści. ${ }^{3}$ „Księgą” tą jest metodologiczny naturalizm. ${ }^{4}$

Później zorientowałem się, że ID [teoria inteligentnego projektu] ma jeszcze inne EUO, ani naturalizm, ani nadnaturalizm, tylko (i tu wymyśliłem nazwę) artyficjalizm jako przeciwieństwo naturalizmu, ale inaczej rozumianego niż w poprzednim sporze [ewolucjonizm-kreacjonizm]. ${ }^{5}$

W myśl tego podejścia funkcjonują zatem cztery EUO, które układają się w następujące pary:

naturalizm antynadnaturalistyczny — nadnaturalizm;

naturalizm antyartyficjalistyczny — artyficjalizm.

Idea EUO jest rozszerzeniem idei uteoretyzowania obserwacji. Jeśli nie ma nagich faktów i wszystkie fakty zinterpretowane są w jakiejś ramie teoretycznej, to nie ma też „nagiej nauki”, ta ostatnia zawsze uprawiana jest w jakimś uprzednio zaakceptowanym kontekście. ${ }^{6}$ Koncepcja EUO wiąże się z odrzuceniem

\footnotetext{
${ }^{2}$ Wypowiedź Kazimierza Jodkowskiego w: Piotr ByLICA, Kazimierz Jodkowski, Krzysztof J. Kilian i Dariusz SAgAN, „Dyskusja nad artykułem Adama Groblera, «Słabości eksplanacyjne teorii inteligentnego projektu»”, Filozoficzne Aspekty Genezy 2013, t. 10, s. 53 [17-63], www.na uka-a-religia.uz.zgora.pl/images/FAG/2013.t.10/art.14.pdf (16.01.2018).

${ }^{3}$ Por. wypowiedź Kazimierza Jodkowskiego w: Bylica, Jodkowski, Kilian i Sagan, „Dyskusja nad artykułem Adama Groblera...", s. 53.

${ }^{4}$ Por. Jodkowski, „Uczony w ciemnym budynku...”, s. 59.

${ }^{5}$ Wypowiedź Kazimierza Jodkowskiego. Fragment korespondencji z Krzysztofem Kilianem.

${ }^{6}$ Por. wypowiedź Kazimierza Jodkowskiego w: Bylica, Jodkowski, Kilian i SAgan, „Dyskusja nad artykułem Adama Groblera...”, s. 53. Por. też Jodкоwski, „Uczony w ciemnym budynku...”, s. 58; Piotr ByLICA, Wspólczesny teizm naturalistyczny z punktu widzenia modelu poziomów
} 
ideału bezzałożeniowości oraz $\mathrm{z}$, nie w pełni jeszcze akceptowaną i rozpoznawaną, tezą o nieredukowalnej obecności filozofii w nauce: ${ }^{7}$

naukowcy jako grupa, a zwłaszcza reprezentujące ich organizacje naukowe, najwyraźniej zupełnie nie zdają sobie sprawy z roli, jaką w ich rozumowaniu odgrywa filozofia. ${ }^{8}$

Odrzucenie to łączy się z akceptacją tezy o założeniowości, zgodnie z którą

analizy. Problem dzialania sfery nadnaturalnej w przyrodzie, Biblioteka Filozoficznych Aspektów Genezy, t. 7, Instytut Filozofii Uniwersytetu Zielonogórskiego, Zielona Góra 2016, s. 26, http://tiny.pl/gkdv1 (16.01.2018); Jitse M. vaN DER MeER, „Przekonania towarzyszące, ideologia i nauka”, przeł. Dariusz Sagan, Filozoficzne Aspekty Genezy 2016, t. 13, s. 154-155 [153-194], http:/www.nauka-a-religia.uz.zgora.pl/images/FAG/2016.t.13/art.04.pdf (13.0.2018); Del RATzscH, „Teologia naturalna, naturalizm metodologiczny i «żółwie do samego dołu»”, przeł. Dariusz Sagan, Filozoficzne Aspekty Genezy 2016, t. 13, s. 119-124 [119-152], http://www.nauka-a-reli gia.uz.zgora.pl/images/FAG/2016.t.13/art.03.pdf (13.01.2018).

${ }^{7}$ Por. Kazimierz JodKowski, „Metafizyczne opowieści nauki jako fundament pluralizmu naukowego", w: Phillip E. JoHnson, Wielka metafizyczna opowieść nauki (z posłowiem Kazimierza Jodkowskiego), przeł. Piotr Bylica, Archiwum Na Poczatku ..., z. 13, Polskie Towarzystwo Kreacjonistyczne, Warszawa 2003, s. 80-81 [74-85], www.nauka-a-religia.uz.zgora.pl/images/ Przedruki/Jodkowski Metafizyczne.opowiesci.nauki.pdf (18.01.2018); Kazimierz JoDKowsKI, „Twarde jądro ewolucjonizmu”, Roczniki Filozoficzne 2003, t. 51, z. 3, s. 78-79 [77-117], http://ti ny.pl/q3m5j (18.01.2018); Kazimierz JoDKowsKI, „Jaka geometria obowiązuje we Wszechświecie?", w: Zbigniew PietrzaK (red.), Albert Einstein i rewolucja relatywistyczna, Lectiones \& Acroases Philosophicae 2016, t. IX, nr 1, s. 87-88 [71-89], www.nauka-a-religia.uz.zgora.pl/images/ Przedruki/Jodkowski_Jaka.geometria.obowiazuje.we.wszechswiecie.pdf (16.01.2018); Kazimierz JodKowski, „Ruch kreacjonistyczny jest elementem pluralizmu naukowego”, Przegląd Filozoficzny - Nowa Seria 2001, R. X, nr 1 (37), s. 242 [241-253], www.nauka-a-religia.uz.zgora.pl/ima ges/Przedruki/Jodkowski_Ruch.kreacjonistyczny.jest.elementem.pluralizmu.naukowego.pdf (08. 01.2018); Kazimierz JodKowski, „Niedocenianie filozofii. Błąd Phillipa E. Johnsona”, Na Począt$k u \ldots$ 2002, nr 1-2 (151-152), s. 14-19, https://creationism.org.pl/artykuly/KJodkowski\#txt2 (15. 01.2018); Grzegorz BugaJaK, „Adekwatność tezy o rozdzielności płaszczyzn poznawczych. Głos w imieniu mieszkańców «opancerzonego bunkra»", w: Bylica, Kilian, Piotrowski i Sagan (red.), Filozofia — nauka - religia..., s. 179 [173-190], www.nauka-a-religia.uz.zgora.pl/images/Przed ruki/Bugajak Adekwatnosc.tezy.o.rozdzielnosci.plaszczyzn.poznawczych.pdf (17.05.2017); BYLICA, Wspólczesny teizm naturalistyczny..., s. 27; Piotr BYLICA, „Nauka światopoglądowo neutralna?", Fronda 2012, nr 63, s. 79 [67-80], www.nauka-a-religia.uz.zgora.pl/images/Przedruki/Byli ca_Nauka.swiatopogladowo.neutralna.pdf (18.01.2018); Jonathan BARTLETT, „Filozoficzne wady naturalizmu metodologicznego i perspektywy na przyszłość”, przeł. Dariusz Sagan, Filozoficzne Aspekty Genezy 2017, t. 14, s. 56-57 [53-87], http://www.nauka-a-religia.uz.zgora.pl/images/ FAG/2017.t.14/art.02.pdf (19.02.2018); Jacek KWAŚNIEWSKI, „Nauka a religia. Historiografia problemu. Ewolucja poglądów na temat historycznych związków religii i nauki”, Zagadnienia Filozoficzne w Nauce 2011, nr XLIX, s. 179 [149-187], http://tiny.pl/gkdvk (12.02.2018). 
nauka bez fillozoficznych założeń $[\ldots]$ nie może istnieć. ${ }^{9}$

Ta ostatnia teza ma trzy składowe. W myśl pierwszej nauka jako całość

zakłada [...] coś wstępnie o naturze badanej rzeczywistości (a także o sposobach jej badania) ${ }^{10}$

zapewnia poznanie prawdy jedynie tym, którzy dokonali stosownych wyborów kulturowych. ${ }^{11}$

${ }^{8}$ Bartlett, „Filozoficzne wady naturalizmu metodologicznego...”, s. 57. Por. też Tas WALKER, ,Jak obiektywni są naukowcy?”, przeł. Katarzyna Gieremek, Na Początku... 2000, nr 3-4 (127-128), s. 74-76, https://creationism.org.pl/artykuly/TWalker (02.02.2018); Kazimierz JoDKOwSKI, „Filozoficzna natura sporu ewolucjonizm-kreacjonizm. Refleksje po lekturze tekstu Phillipa E. Johnsona”, Na Początku ... 2000, nr 7-8 (131-132), s. 211-217, https://creationism.org.pl/ar tykuly/KJodkowski4 (02.02.2018).

${ }^{9}$ Kazimierz Jodkowski, „Curriculum Vitae”, http://www.ifil.uz.zgora.pl/index.php/pl/o-insty tucie/zaklad-logiki-i-metodologii-nauk/89-prof-zw-dr-hab-kazimierz-jodkowski (08.02.2018).

${ }^{10}$ Jodkowski, „Uczony w ciemnym budynku...”, s. 57. Por. też Kazimierz JodKowski, „Kreacjonizm młodej Ziemi a koncepcja Big Bangu. Poglądy Johna Hartnetta z konstruktywistycznej i eksternalistycznej perspektywy", Filozoficzne Aspekty Genezy 2015, t. 12, s. 74-76 [37-79], http: //www.nauka-a-religia.uz.zgora.pl/images/FAG/2015.t.12/art.12.pdf (14.02.2018); Paul DE VRIES, „Naturalizm w naukach przyrodniczych. Perspektywa chrześcijańska”, przeł. Radosław Plato, Filozoficzne Aspekty Genezy 2011, t. 8, s. 123 [121-135], http://www.nauka-a-religia.uz.zgora.pl/ images/FAG/2011.t.8/art.08.pdf (12.02.2018).

${ }^{11}$ Paul K. Feyerabend, Przeciw metodzie, przeł. Stefan Wiertlewski, Wydawnictwo Siedmioróg, Wrocław 1996, s. 239. Na ten fragment zwraca uwagę Jodkowski:

wypowiedź [...] [ta] brzmi tak, jakby [Feyerabend] mówił [...] o konieczności przyjęcia epistemicznego układu odniesienia przed rozpoczęciem badań naukowych.

Kazimierz JodкоwsкI, „Kreacjoniści przed sądem. Aspekty filozoficzne «małpich procesów»”, w: Jakub Michalczenia, Jadwiga Mizińska i Katarzyna Ossowska (red.), Poszukiwania filozoficzne. Tom I: Nauka, Prawda. Panu Profesorowi Józefowi Dębowskiemu w darze, Instytut Filozofii Uniwersytetu Warmińsko-Mazurskiego w Olsztynie, Olsztyn 2014, s. 186 przyp. 26 [175-198], www.nauka-a-religia.uz.zgora.pl/images/Przedruki/Jodkowski_Kreacjonisci.przed.sad em.Aspekty.filozoficzne.malpich.procesow.pdf (19.01.2018). Por. też wypowiedź Kazimierza Jodkowskiego w: Bylica, Jodkowski, Kilian i SAGAn, „Dyskusja nad artykułem Adama Groblera...", s. 52-53.

Warto w tym miejscu zauważyć, że konieczność ta nie jest powszechnie rozpoznawana: 
A zatem,

zanim ktokolwiek rozpocznie uprawianie nauki, musi apriorycznie określić (może być to i najczęściej jest nieświadome), na czym to uprawianie nauki polega. ${ }^{12}$

Zgodnie $\mathrm{z}$ drugą składową $\mathrm{w}$ ramach nauki istnieje możliwość rewizji jej podstawowych założeń:

Czy można uprawiać naukę bez przyjęcia jakiegoś epistemicznego układu odniesienia? Można nie przyjmować tego czy innego, ale jakiś trzeba przyjąć. Zanim zaczniemy szukać przyczyn dla wyjaśnianych zjawisk, musimy zdecydować, gdzie i jak będziemy ich szukać. ${ }^{13}$

W myśl trzeciej składowej w poznaniu naukowym występują nieusuwalne, lecz zmienne, metafizyczne komponenty teorii naukowych. ${ }^{14}$

istnieje tylko jeden rodzaj prawdy naukowej, niezależny od narodowości i wiary praktykujących.

Jerry A. Coyne, „Science, Religion, and Society: The Problem of Evolution in America”, Evolution. International Journal of Organic Evolution 2012, vol. 66, no. 8, s. 2656 [2654-2663], http://onlinelibrary.wiley.com/doi/10.1111/evo.2012.66.issue-8/issuetoc (30.01.2018).

${ }^{12}$ Wypowiedź Kazimierza Jodkowskiego w: Bylica, Jodkowski, Kilian i SAGan, „Dyskusja nad artykułem Adama Groblera...”, s. 51. Por. też Kazimierz JodKowski, „Racjonalność Kopernika i Darwina. Polemika z drem Eugeniuszem Moczydłowskim”, Na Początku... 2003, nr 11-12A (174-175), s. 435 [433-448], www.nauka-a-religia.uz.zgora.pl/images/Przedruki/Jodkowski_Rac jonalnosc.Kopernika.i.Darwina.pdf (14.02.2018).

${ }^{13}$ Kazimierz Jodkowski, „Nienaukowy fundament nauki”, w: Zbigniew Pietrzak (red.), Granice nauki, Lectiones \& Acroases Philosophicae 2013, t. VI, nr 1, s. 105 [59-108], www.nauka-areligia.uz.zgora.pl/images/Przedruki/Jodkowski_Nienaukowy.fundament.nauki.pdf (18.01.2018).

${ }^{14}$ Por. Jodkowski, „Metafizyczne opowieści nauki...”, s. 80-81; Jodkowski, „Curriculum Vitae...”; Kazimierz Jodkowski, „Przedmowa”, Filozoficzne Aspekty Genezy 2004, t. 1, s. 5-6 [5-6], www.nauka-a-religia.uz.zgora.pl/images/FAG/2004.t.1/art.09.pdf (02.02.2018); Piotr ByLICA, „Kazimierza Jodkowskiego koncepcja epistemicznych układów odniesienia a teizm naturalistyczny Johna Polkinghorne'a”, w: Bylica, Kilian, Piotrowski i Sagan (red.), Filozofia - nauka — religia...., s. 192-193 [191-211], www.nauka-a-religia.uz.zgora.pl/images/Przedruki/Bylica Kazimierza.Jodkowskiego.koncepcja.epistemicznych.ukladow.odniesienia.pdf (18.01.2018); Mario A. LóPEz, „Projekt jako kryterium demarkacji”, przeł. Dariusz Sagan, Filozoficzne Aspekty Genezy 2016, t. 13, s. 77 [75-100], www.nauka-a-religia.uz.zgora.pl/images/FAG/2016.t.13/art.12. $\operatorname{pdf}(12.01 .2018)$. 
Nazwa „epistemiczny układ odniesienia” pojawia się nie tylko w pismach członków Zielonogórskiej Grupy Lokalnej „Nauka a Religia”. ${ }^{15}$ Zaś sama idea EUO też już jest rozpoznawalna. Przykładowo konieczny warunek naturalistycznego uprawiania nauki charakteryzowany jest przez

podstawowy epistemologiczny i metodologiczny układ odniesienia (basic epistemological and metaphysical framework), który albo wyklucza istnienie Boga, lub, co najmniej, umieszcza Go całkowicie poza granicami przyrodniczego wszechświata. ${ }^{16}$

Mówi się też o połączeniu sposobów ograniczania badań z systemami uzasadnień:

Jako metodologiczny układ odniesienia (methodological framework ${ }^{17}$ ) naturalizm metodologiczny ogranicza się do obiektów wykazujących zachowanie mechaniczne, a jako system uzasadniania obiera pozytywizm. ${ }^{18}$

Mówi się również o sieciach podstawowych przekonań konstytuujących naukowy obraz świata:

w każdym eksperymencie uczeni korzystają z sądów dotyczących tego, co powinno być uznawane za dane empiryczne. Uczeni konstruują te sądy w zgodzie z całą siatką podstawowych przekonań. [...] przekonania takie są pojęciami i intuicjami, które stanowią dodatek obserwatora. Pojęcia takie $[\ldots]$ działają jako rodzaj sieci, za pomocą której uczony łowi swoje obserwacje. Takie twórcze mentalne dodatki muszą być presuponowane po to, by zachodziła zgodność ze światem zewnętrznym wobec obserwatora. ${ }^{19}$

\footnotetext{
${ }^{15}$ Por. http://www.nauka-a-religia.uz.zgora.pl/index.php/pl/grupa-lokalna. Por. też np. RosKAL, „Eksperyment MacDougalla...”, s. 165-172; Radosław KAziBut, „Filozoficzna gramatyka praktyki laboratoryjnej Hasoka Changa a epistemiczny układ odniesienia Roberta Boyle'a", w: Lidia Godek, Maciej Musią i Marek Woszczak (red.), X Polski Zjazd Filozoficzny. Księga streszczeń, Wydawnictwo Naukowe Instytutu Filozofii UAM, Poznań 2015, s. 419-420.

${ }^{16}$ Por. Thomas NAgel, „Public Education and Intelligent Design”, Philosophy \& Public Affairs 2008, vol. 36, no. 2, s. 205 [187-205].

${ }^{17}$ Jonathan BARTLETt, „Philosophical Shortcomings of Methodological Naturalism and the Path Forward", w: Jonathan Bartlett and Eric Holloway (eds.), Naturalism and Its Alternatives in Scientific Methodologies: Proceedings of the 2016 Conference on Alternatives to Methodological Naturalism, Blyth Institute Press, Broken Arrow, Oklahoma 2017, s. 32-33 [13-37], http://tiny.pl/gkdb2 (18.01.2018).

${ }^{18}$ BARTLETT, „Filozoficzne wady naturalizmu metodologicznego...”, s. 82.
} 
Używa się także określeń „naturalistyczne teorie nauki” i „nienaturalistyczne teorie nauki" dla oznaczenia rodzaju założeń wyjściowych, jakie teorie te dopuszczają. ${ }^{20}$ Funkcjonują też nazwy: ,interpretatywny układ odniesienia” (interpretive framework) i „teoretyczny układ odniesienia”. Ta pierwsza oznacza narzędzie służące do oceniania faktów pod kątem ich zgodności z przyjmowanymi uprzednio założeniami teoretycznymi. ${ }^{21}$ Ta druga oznacza perspektywę teoretyczną, przez pryzmat której analizuje się badane zagadnienie. ${ }^{22}$

\section{EUO - definicja, odmiany i ich twarde jądra}

EUO to, przyjmowane na mocy decyzji uczonych, niewielkie, dwu- lub trzyelementowe zbiory najogólniejszych, historycznie zmiennych założeń, które określają konieczne warunki uprawiania nauki.

Założeń tych nie da się naukowo uzasadnić bez popadnięcia w błędne koło, gdyż wszelkie, uznawane za naukowe, badania już je przyjmują. ${ }^{23}$ Założenia te mówią, co, według danej grupy uczonych, jest w praktyce naukowej zakazane, a co nie - wskazują, jak można uprawiać naukę i jak tego robić nie można. Wyznaczają przez to zakres dopuszczalnych rozwiązań problemów. Pośrednio informują też uczonych o tym, co istnieje, przez co wyznaczają również najogólniejszą perspektywę metafizyczną uprawiania nauki. ${ }^{24}$

${ }^{19}$ Stephen C. Meyer, „Scientific Tenets of Faith”, Journal of the American Scientific Affiliation 1986, vol. 38, no. 1, http://www.arn.org/docs/meyer/sm_scientifictenets.htm (13.02.2018).

${ }^{20}$ Por. Eric HollowaY, „Problems With Non-Naturalistic Theories of Science”, w: Bartlett and Holloway (eds.), Naturalism and Its Alternatives..., s. 163 [163-176].

${ }^{21}$ Por. David E. Shormann, ,, The Revolution of Creationism”, Creation Matters 2012, vol. 17, no. 6, s. 1-2 [1-3], http://tiny.pl/gnlgn (20.02.2018); Marta Cuberbiller, „Metodologiczne korzyści z istnienia teorii kreacjonistycznych", w: Małgorzata GAZDA (red.), Idź Pod Prąd w sporze ewolucjonizm-kreacjonizm, Wydawnictwo POD PRĄD, Lublin 2017, s. 45-48.

${ }^{22}$ Por. Andrzej Zybertowicz z zespołem, Samobójstwo Oświecenia?, Wydawnictwo Kasper, Kraków 2015, s. 21.

${ }^{23}$ Por. JodKowski, „Epistemiczne układy odniesienia i «warunek Jodkowskiego»...”, s. 115; Robert A. Larmer, „Is Methodological Naturalism Question-Begging?”, Philosophia Christi 2003, vol. 5, no. 1, s. 117-118, 130 [113-130], www.epsociety.org/userfiles/art-Larmer\%20(Methodologi calNaturalismQuestion-Begging).pdf (01.01.2018). Larmer swój argument sformułował jedynie dla naturalizmu metodologicznego. 
Zauważono, że EUO można próbować uzasadniać z poziomu metanaukowego: jeśli spośród alternatywnych hipotez naukowych wybiera się taką, która proponuje najlepsze wyjaśnienie zjawisk $\mathrm{w}$ danej dziedzinie, to, kierując się tą samą zasadą, spośród alternatywnych EUO należy wybrać taki, który lepiej od innych kieruje pracami badawczymi w danej dziedzinie. Oto przykład takiej próby:

naturalizm był główną przesłanką w myśleniu Darwina, a sukces jego teorii mocno poparł słuszność naturalizmu, pokazując, że nadnaturalne ujęcie rzekomego projektu świata było powierzchowne. ${ }^{25}$

Przyjęcie tego metanaukowego uzasadnienia uzależnione jest jednak od odrzucenia tezy o niewspółmierności. ${ }^{26}$ Odrzucona musi zostać również teza

\footnotetext{
${ }^{24}$ Por. wypowiedź Kazimierza Jodkowskiego w: Adam Willma, „Przyroda, Bóg, nauka. Rozmowa z profesorem Kazimierzem Jodkowskim”, Gazeta Pomorska 2 listopada 2006, s. 7, www. nauka-a-religia.uz.zgora.pl/images/Przedruki/Jodkowski Przyroda.Bog.nauka.pdf (18.01.2018); Kazimierz Jodkowski, „Dlaczego kreacjonizm jest pseudonauką?”, w: Józef ZoN (red.), Pogranicza nauki. Protonauka - paranauka - pseudonauka, Wydawnictwo KUL, Lublin 2009, s. 322 [317-323], www.nauka-a-religia.uz.zgora.pl/images/Przedruki/Jodkowski_Dlaczego.kreacjonizm. jest.pseudonauka.pdf (31.01.2018); JoDKowski, „Nienaukowy fundament nauki...”, s. 100-105; Kazimierz JoDKowski, „Eskapizm teologii i filozofii katolickiej w sprawie «nauka a religia»”, $N a$ Poczatku... 2005, nr 7-8 (196-197), s. 273-274 [261-284], www.nauka-a-religia.uz.zgora.pl/image s/Przedruki/Jodkowski_Eskapizm.teologii.i.filozofii.katolickiej.pdf (18.01.2018); Kazimierz JODKowsKI, „Zasadnicza nierozstrzygalność sporu ewolucjonizm-kreacjonizm”, Przeglad Filozoficzny - Nowa Seria 2012, nr 3 (83), s. 215 [201-222], www.nauka-a-religia.uz.zgora.pl/images/Przedru ki/Jodkowski_Zasadnicza.nierozstrzygalnosc.sporu.ewolucjonizm.kreacjonizm.pdf (18.05.2017); Kazimierz JoDKowski, „Epistemiczny układ odniesienia teorii inteligentnego projektu”, Filozofia Nauki 2006, nr 1 (53), s. 97-98 [95-105], www.nauka-a-religia.uz.zgora.pl/images/Inne.teksty/Jod kowski_Epistemiczny.uklad.odniesienia.teorii.ID.pdf (18.01.2018); BuGAJAK, „Adekwatność tezy o rozdzielności płaszczyzn poznawczych...", s. 179. Por. też BYLICA, Współczesny teizm naturalistyczny...., s. 26; Ernan McMulun, „Odmiany naturalizmu metodologicznego”, przeł. Ewelina Topolska, Filozoficzne Aspekty Genezy 2012, t. 9, s. 109 [109-129], http://www.nauka-a-religia. uz.zgora.pl/images/FAG/2012.t.9/art.02.pdf (20.01.2018).

${ }^{25}$ David R. OldRoyd, Darwinian Impacts: An Introduction to the Darwinian Revolution, Humanities Press, Atlantic Highlands, New Jersey 1980, s. 254 (cyt. za: Kazimierz JodKowski, „Antynaturalizm teorii inteligentnego projektu”, Roczniki Filozoficzne 2006, t. 54, nr 2, s. 65 [63-76], www.nauka-a-religia.uz.zgora.pl/images/Przedruki/Jodkowski_Antynaturalizm.teorii.ID. pdf [16.02.2018]).

${ }^{26}$ Problematyka interteoretycznej niewspółmierności łączy się z podejściem antykumulatywistycznym. Zwolennicy tego ostatniego kwestionują szeroko rozpowszechniony pogląd, wedle którego obecnie przyjmowane teorie naukowe są pozbawione przesądów, a przez to bardziej racjonalne, oparte na większej ilości obserwacji, dzięki czemu są bardziej wiarogodne, obejmują
} 
o stratach. ${ }^{27}$ I dlatego taka próba uzasadnienia ma istotne ograniczenia. ${ }^{28}$

Jedynym powszechnie znanym i dobrze opisanym we współczesnej filozofii nauki EUO jest metodologiczny naturalizm - nakaz ograniczania badań naukowych do świata przyrody, a co za tym idzie nakaz przyjmowania jedynie naturalistycznych wyjaśnień dla faktów i procesów, wraz z jednoczesnym zakazem przyjmowania wyjaśnień powołujących się na przyczyny nadnaturalne: ${ }^{29}$

większy zakres zjawisk, a przez to są szersze, wyjaśniają badany aspekt świata przy użyciu mniejszej ilości fundamentalnych zasad, co czyni je teoriami głębszymi od teorii już porzuconych. Wyraźnie odstępują oni od tradycyjnego poglądu, że nowo formułowane teorie muszą być zgodne ze swoimi poprzedniczkami, ponieważ tamte dotyczyły częściowo tego samego zakresu zjawisk, twierdząc, że w dziejach nauki zaobserwować można takie przypadki, gdy następujące po sobie teorie są niewspółmierne - w pewnym sensie i pod pewnymi względami nieporównywalne.

Przykłady niewspółmiernych ujęć to przechodzenie od doktryn stałych gatunków do biologii ewolucyjnej, od Arystotelesowskiej do Locke'owskiej teorii barw, od mechaniki arystotelesowskiej do teorii impetu, od teorii impetu do mechaniki newtonowskiej, od mechaniki newtonowskiej do szczególnej i ogólnej teorii względności. Przyjmuje się również, że teorie mogą też być niewspółmierne z pojedynczymi twierdzeniami. Niewspółmierność zachodzić może także między teorią a poszczególnymi prawami. Mówi się też o niewspółmiernych ramach roboczych czy systemach pojęciowych. Najczęściej mówi się o relacji niewspółmierności zachodzącej między teoriami naukowymi (por. np. Paul K. Feyerabend, „Changing Patterns of Reconstruction”, British Journal for the Philosophy of Science 1977, vol. 28, no. 4, s. 363-365 [351-369]; Paul K. FeYERABEND, Science in a Free Society, Verso, London 1983, s. 66-68; Imre Lakatos and Paul K. Feyerabend, For and Against Method: Including Lakatos's Lectures on Scientific Method and the Lakatos-Feyerabend Correspondence, ed. Matteo Motterlini, The University of Chicago Press, Chicago - London 1999, s. 133 przyp. 20 (dodany przez Motterliniego); Kazimierz JoDKowski, „Filozofia nauki Paula K. Feyerabenda. Stadium umiarkowane”, Studia Filozoficzne 1979, nr 11 (168), s. 64, 70, 73 [59-75]; Kazimierz JodKowski, „O dwu rodzajach niewspółmierności interteoretycznej w ujęciu Paula K. Feyerabenda”, Studia Filozoficzne 1980, nr 7, s. 80, 83, 91 [79-91]; Kazimierz JoDKowski, „Problem wyboru spośród niewspółmiernych teorii (analiza stanowiska P.K. Feyerabenda z tzw. okresu umiarkowanego)”, Studia Filozoficzne 1984, nr 1 (218), s. 109110, 112 [109-120]; Kazimierz JoDKowsKi, Teza o niewspólmierności w ujęciu Thomasa S. Kuhna i Paula K. Feyerabenda, Realizm. Racjonalność. Relatywizm, t. 1, Wydawnictwo UMCS, Lublin 1984, s. 8-9, 35-37, 49-50, 58, 86; Kazimierz JodKowski, „Nauka w oczach Feyerabenda”, w: Kazimierz Jodкоwski (red.), Czy sprzeczność może być racjonalna?, Realizm. Racjonalność. Relatywizm, t. 4, Wydawnictwo UMCS, Lublin 1986, s. 239-240 [227-270]; Kazimierz JodKowsKi, Wspólnoty uczonych, paradygmaty i rewolucje naukowe, Realizm. Racjonalność. Relatywizm, t. 22, Wydawnictwo UMCS, Lublin 1990, s. 116; Krzysztof J. KiLIan, Poglądy filozoficzne Paula K. Feyerabenda. Część I. Program metodologiczny, Oficyna Wydawnicza Uniwersytetu Zielonogórskiego, Zielona Góra 2014, s. 51-57).

Odnosząc to do podejmowanego tu problemu, powiedzieć można, że interteoretyczna niewspółmierność jest efektem tego, że w ramach niektórych, rywalizujących ze sobą lub po sobie 
Alternatywą [dla naturalizmu] jest wyłączenie [...] ze wspólnoty naukowej. ${ }^{30}$

Uprawiający naukę muszą dostosować się [do wymogów naturalizmu metodologicznego] lub zostaną wykluczeni z życia naukowego. ${ }^{31}$

Nakaz ten w swojej pierwotnej wersji wymierzony był w podejścia dopuszczające wyjaśnienia nadnaturalistyczne: ${ }^{32}$

przypuszczenie, że każdy gatunek powstał tylko na jednym, pierwotnym obszarze, urzeka swą prostotą. Kto odrzuca to przypuszczenie, odrzuca także vera $[\mathrm{m}]$ causa $[\mathrm{m}]$

następujących teorii naukowych odmiennie postrzega się świat. Przykładowo akceptacja naturalizmu metodologicznego wyklucza ujmowanie podobieństw między organizmami jako efektu, obmyślonego przez inteligentnego projektanta, wspólnego planu (por. np. William B. Provine, „Projekt? Tak! Ale czy inteligentny?", przeł. Sławomir Piechaczek, Filozoficzne Aspekty Genezy 2005/ 2006, t. 2/3, s. 224 [217-237], www.nauka-a-religia.uz.zgora.pl/images/FAG/2005-2006.t.2-3/art. 10.pdf [01.02.2018]).

Teorie niewspółmierne posługują się również odmiennymi metodami badawczymi lub różnymi standardami oceny tego, co jest w danym momencie uznawane za nauke. Na przykład zgodnie z artyficjalizmem niektóre cechy świata ożywionego wskazują, że są efektem ingerencji inteligentnego projektanta, gdyż nie mogły powstać w sposób naturalny, zaś dla zwolenników naturalizmu metodologicznego jest to pseudoproblem, gdyż naturalistycznie uprawiana nauka nie dopuszcza wyjaśnień nienaturalistycznych (por. np. Douglas J. FutuyMA, „Cuda a molekuły”, przeł. Dariusz Sagan, Filozoficzne Aspekty Genezy 2004, t. 1, s. 68 [65-69], www.nauka-a-religia.uz. zgora.p1/images/FAG/2004.t.1/art.03.pdf [03.02.2018]).

Niewspółmierne podejścia mówią także o różnych przedmiotach za pomocą tych samych słów. Przykładem zmiany znaczeniowej jest sposób rozumienia pojęcia doboru naturalnego przez ewolucjonistów i kreacjonistów. Dla tych pierwszych dobór naturalny jest siłą napędową ewolucji, czynnikiem sprawczym makroewolucji - powstawania nowych gatunków, zaś przez tych drugich uznawany jest jedynie za czynnik zachowawczy, utrzymujący gatunek w zdrowiu i sile poprzez usuwanie osobników słabych i zniekształconych (por. np. wypowiedź Michała Chaberka w: Tomasz RowiŃski, „Dlaczego warto nauczać «dwóch stron»? O edukacji, ewolucji i teorii inteligentnego projektu. Rozmowa z o. Michałem Chaberkiem, dominikaninem, doktorem teologii fundamentalnej, autorem książki Stworzenie czy ewolucja? Dylemat katolika", Christianitas 2014, nr 58, s. 79 [70-82], http://christianitas.org/news/dlaczego-warto-nauczac-dwoch-stron-oedukacji-ewolucji-i-teorii-inteligentnego-projektu [23.01.2018]).

Teorie niewspółmierne postulują też istnienie różnych zbiorów przedmiotów, procesów czy zjawisk. Przykładowo zgodnie z naturalizmem wszystkie zjawiska i procesy w świecie mają materialne przyczyny, zaś wedle nadnaturalizmu istnieją zjawiska i procesy, które takich przyczyn nie mają.

${ }^{27}$ W myśl Kuhnowskiej tezy o stratach następstwem międzyparadygmatycznej zmiany reguł gry jest to, że niektóre wcześniejsze osiągnięcia uznawane są za bezwartościowe. Na poziomie wyjaśniania faktów proces rozwoju nauki charakteryzują zarówno straty, jak i zyski. Niektóre fakty, uprzednio uznawane za wiarygodne, są usuwane z obszaru nauki. Obarczane są niezauważal- 
zwykłego powstania i następnego rozpowszechnienia gatunków, a odwołuje się do cudu. ${ }^{33}$

Tak sformułowany nakaz wyjaśnień naturalistycznych wymaga pewnego komentarza. Rozpowszechnienie teorii inteligentnego projektu (ID) wymusiło na zwolennikach naturalizmu metodologicznego modyfikację wyżej scharakteryzowanego nakazu tak, aby, obok przyczyn nadnaturalnych, wykluczał również przyczyny inteligentne (sztuczne), do których odwołuje się ID: ${ }^{34}$

nym poprzednio błędem lub uznawane za nieistotne dla nauki, lub też stwierdza się, że stany rzeczy, o jakich mówiły te fakty, po prostu nie zachodzą (por. Thomas S. Kunn, Struktura rewolucji naukowych, przeł. Helena Ostromęcka i Justyna Nowotniak, Aletheia, Warszawa 2001, s. 191192; JodKowski, Wspólnoty uczonych..., s. 157 przyp. 60; Kazimierz JoDKowski, „Interpretacje Kuhnowskiej tezy o niewspółmierności”, Roczniki Filozoficzne 1984, t. 32, z. 3, s. 175 [173-198]; Rein Vihalemm, „The Kuhn-Loss Thesis and the Case of Phlogiston Theory”, Science Studies 2000, vol. 13, no. 1 , s. 71 [68-78].

${ }^{28}$ Por. Krzysztof J. Kilian, „Wzrost wiedzy a zasada tolerancji”, w: Michalczenia, MizińsKa i OssowsKa (red.), Poszukiwania filozoficzne. T. I..., s. 159-161 [155-173].

${ }^{29}$ Por. Kazimierz JodKowsKI, „Rozpoznawanie genezy: istota sporu ewolucjonizm-kreacjonizm”, Roczniki Filozoficzne 2002, t. 50, z. 3, s. 189 [187-198], www.nauka-a-religia.uz.zgora.pl/ images/Przedruki/Jodkowski_Rozpoznawanie.genezy.pdf (19.01.2018); JodKowsKI, „Zasadnicza nierozstrzygalność...”, s. 216; JodKowski, „Twarde jądro ewolucjonizmu...”, s. 85; JodKowski, „Uczony w ciemnym budynku...”, s. 59; Dariusz SAGAN, „Naturalizm metodologiczny — konieczny warunek naukowości?", Roczniki Filozoficzne 2013, t. LXI, nr 1, s. 73-74 i 81-82 [7391], www.nauka-a-religia.uz.zgora.pl/images/Przedruki/Sagan Naturalizm.metodologiczny.konie czny.warunek.naukowosci.pdf (04.02.2018); Piotr ByLIcA, „Zaburzenia dysocjacyjne czy opętanie przez Szatana. Historyczno-metodologiczna analiza stosunku psychiatrii do problemu opętań", w: ZoN (red.), Pogranicza nauki..., s. 218-219 [209-225], www.nauka-a-religia.uz.zgora.pl/images/ Przedruki/Bylica_Zaburzenia.dysocjacyjne.pdf (04.02.2018); Piotr BYLICA, „Główne założenia i problemy teizmu naturalistycznego w sprawie relacji sfery nadprzyrodzonej i świata przyrodniczego", w: Wiesław Dүк (red.), Sozologia systemowa. Biosfera. Czlowiek i jego środowisko w aspekcie przyrodniczym, filozoficznym i teologicznym, Wydawnictwo Naukowe Uniwersytetu Szczecińskiego, Szczecin 2012, s. 74 [55-95], www.nauka-a-religia.uz.zgora.pl/images/Przedruki/ Bylica_Glowne.zalozenia.teizmu.naturalistycznego.pdf (31.01.2018); Piotr ByLICA, „Naturalizm metodologiczny jako warunek naukowości w kontekście relacji nauki i religii”, Przeglad Filozoficzny - Nowa Seria 2004, R. 13, nr 3 (51), s. 164-165 [163-175], www.nauka-a-religia.uz. zgora.pl/images/Przedruki/Bylica Naturalizm.metodologiczny.jako.warunek.naukowosci.pdf (04. 02.2018); James Porter Moreland and William Lane Craig, Philosophical Foundations for a Christian Worldview, InterVarsity Press, Downers Grove 2003, s. 358.

Zauważono też, że w niektórych sytuacjach „,wyjaśnienia są nienaukowe nie tylko dlatego, że powołują się na nadnaturalne przyczyny, ale także wówczas, gdy badane są [jedynie] indywidualne przypadki” (Roskal, „Eksperyment MacDougalla...”, s. 171). Por. też wypowiedzi Andrzeja Elżanowskiego i Kazimierza Jodkowskiego w: Bartosz Borczyк, Adam CHмIELEwski, An- 
celowa organizacja istot żywych mogła powstać wskutek działania przyrodniczego procesu — selekcji naturalnej — i [...] w ogóle nie trzeba powoływać się na Stwórcę lub inną zewnętrzną przyczynę. ${ }^{35}$

Jak powszechnie wiadomo, osią sporu o charakter dopuszczalnych wyjaśnień są nauki o życiu. ${ }^{36}$ Dlatego kryterium to formułowano przede wszystkim dla tych nauk. ${ }^{37}$

drzej Elżanowski, Kazimierz Jodkowski, Damian Leszczyński, Jerzy Lukierski, Łukasz Nysler i Bogusław PawŁowski, „Dyskusja”, w: Damian Leszczyński (red.), Ewolucja, filozofia, religia, Lectiones \& Acroases Philosophicae 2010, vol. III, s. 167-169 [155-172], www.nauka-a-religia. uz.zgora.pl/images/Przedruki/Jodkowski_Dyskusja.o.Darwinie.pdf (06.02.2018); Adam CenIAN, „Wiara w naukę - jej podstawy, założenia, mocne i słabe strony kultu”, wystąpienie na Konferencji Chrześcijańskiego Forum Pracowników Nauki: Nauka - Etyka - Wiara, Rydzyna 30.0502.06.2013, s. 153 [151-159], http://www.chfpn.pl/files/?id_plik=508 (15.01.2018).

${ }^{30}$ Tor Egil Førland, „Acts of God?: Miracles and Scientific Explanation”, History and Theory 2008, vol. 47, no. 4, s. 493 [483-494], http://www.chss.uqam.ca/Portals/0/docs/his7007/Tor\% 20Egil-Dieu-Hisitoire.pdf (01.01.2018).

${ }^{31}$ Brad S. Gregory, „No Room for God?: History, Science, Metaphysics, and the Study of Religion”, History and Theory 2008, vol. 47, no. 4, s. 497 [495-519], www.chss.uqam.ca/Portals/ 0/docs/his7007/Brad\%20S.\%20Gregory.pdf (01.01.2018).

${ }^{32}$ Por. w tej sprawie uwagi Kazimierza JodKowskIEGo, „Antynaturalizm teorii inteligentnego projektu...", s. 64.

${ }^{33}$ Karol DARwIN, O powstawaniu gatunków drogą doboru naturalnego czyli o utrzymaniu się doskonalszych ras w walce o byt. Dziela wybrane, t. 2, przeł. Szymon Dickstein i Józef Nusbaum, Państwowe Wydawnictwo Rolnicze i Leśne, Warszawa 1959, s. 386.

Nieco później Darwin wystąpił również przeciwko wyjaśnieniom teleologicznym:

Nie więcej jest, zdaje się, celowości w zmienności istot żywych i w działaniu doboru naturalnego niż w kierunku, w którym wieje wiatr.

Karol Darwin, Autobiografia i wybór listów. Dziela wybrane, t. 8, przeł. Anna Iwanowska, Aniela Makarewicz, Anna Straszewicz i Zdzisława Wójcik, Państwowe Wydawnictwo Rolnicze i Leśne, Warszawa 1960, s. 44. Por. też Karol DARwIN, Zmienność zwierząt i roślin w stanie udomowienia. Dzieła wybrane, t. 3, przeł. Kazimierz Brończyk, Państwowe Wydawnictwo Rolnicze i Leśne, Warszawa 1959, s. 403; JoDKOwsKI, „Antynaturalizm teorii inteligentnego projektu...”, s. 73.

${ }^{34}$ Por. Franklin M. HAROLD, The Way of the Cell: Molecules, Organisms, and the Order of Life, Oxford University Press, Oxford 2001, s. 205; Michał Heller, „Nie za bardzo inteligentny projekt”, Copernicus Center 24 grudnia 2014, https://www.copernicuscenter.edu.pl/nie-za-bardzo- 
Uzupełniony o dodatkowy zakaz, wymóg naturalizmu metodologicznego staje się nakazem przyjmowania jedynie naturalistycznych wyjaśnień dla faktów i procesów, wraz z jednoczesnym zakazem przyjmowania wyjaśnień antynaturalistycznych, czyli wyjaśnień powołujących się na przyczyny nadnaturalne (antynaturalizm 1 ) i inteligentne (antynaturalizm ${ }_{2}$ ). De facto mówi się tu o dwóch odmianach antynaturalizmu, co odpowiada wyróżnionym wcześniej dwu parom EUO. Do problemu tego powrócę po przedstawieniu pewnego wniosku, jaki nasuwa się $\mathrm{z}$ uwzględnienia $\mathrm{w}$ podejściu naturalistycznym antynaturalizmu artyficjalistycznego (antynaturalizmu ${ }_{2}$ ) i następującej po tym wniosku charakterystyce tego podejścia.

Wzbogacony o akceptację wykluczenia wyjaśnień artyficjalistycznych, wymóg naturalizmu metodologicznego staje się warunkiem nieadekwatnym, bo niezgodnym z tym, co na co dzień robi się w nauce. Wiedzie bowiem do uznania za nienaukowe tych dyscyplin, którym powszechnie nie odmawia się statusu na-

inteligentny-inteligentny-projekt-25312 (10.02.2018); Michał HeLler, „Konieczność i przypadek w ewolucji Wszechświata", Zagadnienia Filozoficzne w Nauce 2009, t. XLIV, s. 11 [3-12], http:// zfn.edu.pl/index.php/zfn/article/download/208/198 (30.01.2018); Jerry A. Coyne, „Nowa fala fanatyzmu w nauce", przeł. Dariusz Sagan, Filozoficzne Aspekty Genezy 2004, t. 1, s. 51-52 [4953], http://www.nauka-a-religia.uz.zgora.pl/images/FAG/2004.t.1/art.01.pdf (02.02.2018). Por. też JoDKOWSKI, „Antynaturalizm teorii inteligentnego projektu...”, s. 68-72.

${ }^{35}$ Francisco J. Ayala, „Darwin's Revolution”, w: John H. CAmpbell and J.W. Schoff (eds.), Creative Evolution!?, Jones and Bartlett, New York 1994, s. 4-5 [1-18] (cyt. za: Stephen C. MEYER, „Demarkacja nauki i religii”, przeł. Joanna Popek, Filozoficzne Aspekty Genezy 2009/2010, t. 6/7, s. 181 [177-196], http://www.nauka-a-religia.uz.zgora.pl/images/FAG/2009-2010.t.6-7/art. 11.pdf [26.01.2018]). Por. też Krzysztof ŁasTOWSKI, „Kilka uwag o sporze ewolucjonizmu z «naukowym kreacjonizmem» w związku z książką K. Jodkowskiego Metodologiczne aspekty kontrowersji ewolucjonizm-kreacjonizm", Przegląd Filozoficzny - Nowa Seria 2001, R. X, nr 1 (37), s. 231 [229-240], www.nauka-a-religia.uz.zgora.pl/images/Przedruki/Lastowski_Kilka.uwag .o.sporze.ewolucjonizmu.z.naukowym.kreacjonizmem.pdf (08.02.2018).

${ }^{36}$ Por. Christian DE Duve, „The Beginning of Life on Earth”, American Scientist 1995, vol. 83, s. 428 [428-437], http://pratclif.com/memes/deduve-begin-life1.html (07.02.2018); Kazimierz JoDKошsкI, Metodologiczne aspekty kontrowersji ewolucjonizm-kreacjonizm, Realizm. Racjonalność. Relatywizm, t. 35, Wydawnictwo UMCS, Lublin 1998, s. 292; Piotr Bylica, „Spór o naukowość teorii inteligentnego projektu”, w: Kazimierz JoDKOWSKI (red.), Teoria inteligentnego projektu - nowe rozumienie naukowości?, Biblioteka Filozoficznych Aspektów Genezy, t. 2, Wydawnictwo MEGAS, Warszawa 2007, s. 62-63 [51-78], www.nauka-a-religia.uz.zgora.pl/ima ges/Przedruki/Bylica_Spor.o.naukowosc.teorii.ID.pdf (14.02.2018).

${ }^{37}$ Por. JodKowsKi, „Antynaturalizm teorii inteligentnego projektu...”, s. 73. 
ukowości. ${ }^{38}$ Istnieją dyscypliny (na przykład archeologia), które dopuszczają wyjaśnienia nienaturalistyczne (archeologowie niejednokrotnie stwierdzają, że odkryte przez nich przedmioty są wytworami istot inteligentnych), a nikt im nie odmawia pretensji do naukowości: ${ }^{39}$

skoro $\mathrm{w}$ innych naukach, tak humanistycznych, jak i przyrodniczych, dopuszcza się poszukiwanie i odnajdywanie śladów rozumnej aktywności, to nie ma pozaideologicznych powodów, by zabronić tego samego biologom. ${ }^{40}$

Na ogół twierdzi się, że terminem „naturalizm metodologiczny” po raz pierwszy posłużył się amerykański filozof Paul de Vries w 1983 roku. ${ }^{41}$ Wcześniej, bo w 1936 roku, użył go inny amerykański filozof i metodystyczny teolog Edgar Sheffield Brightman (1884-1953) w następującym kontekście:

Każdy myślący eksperymentator dochodził będzie [...] do naturalizmu. Przyjmował będzie, że przyroda to czasoprzestrzenny porządek opisywany przez nauki. [...] Uznawał będzie ten porządek za pozbawiony celu w tym sensie, że większość obiektów naturalnych nie działa celowo, oraz w tym sensie, że cel (za wyjątkiem celu, jakim jest sam opis) jest nieistotny dla większości naukowych opisów. [...] Taki uniwersalny naturalizm - wspólny idealistom i realistom, podobnie jak naturalistom i teistom — na-

\footnotetext{
${ }^{38}$ Por. Larry Laudan, „Zgon kryterium demarkacji”, przeł. Artur Koterski, w: Zbysław MuSZYŃSKI (red.), Z badań nad prawdą, nauką i poznaniem, Realizm. Racjonalność. Relatywizm, t. 31, Wydawnictwo UMCS, Lublin 1998, s. 70 [63-79].

${ }^{39}$ Por. np. Kazimierz JodKowski, „Kreacjonizm a naturalizm nauk przyrodniczych”, Annales Universitatis Mariae Curie-Skłodowska, Sectio I, Lublin-Polonia 1996/1997, vol. XXI i XXII, s. 19-20 [11-26], http://www.nauka-a-religia.uz.zgora.pl/images/Przedruki/Jodkowski_Kreacjoni zm.a.naturalizm.nauk.przyrodniczych.pdf (02.02.2018); SAGAN, „Naturalizm metodologiczny konieczny warunek naukowości...", s. 86.

${ }^{40}$ JoDKowsKI, „Rozpoznawanie genezy...”, s. 194 [wyróżnienie dodane].

${ }^{41}$ Por. Kazimierz JoDKowsKi, „Konflikt nauka-religia a teoria inteligentnego projektu”, w: JoDKошSкI (red.), Teoria inteligentnego projektu..., s. 161 [145-180], http://www.nauka-a-religia. uz.zgora.pl/images/Przedruki/Jodkowski_Konflikt.nauka-religia.a.teoria.ID.pdf (20.01.2018); Harry Lee Poe i Chelsea Rose Mүтүк, „Od metody naukowej do naturalizmu metodologicznego. Ewolucja idei”, przeł. Bartosz Błaszczak, Gerard Dmuch, Ewa Komorowska, Iwona Kumiszcze, Izabela Obłaczyńska, Katarzyna Piłka, Radosław Plato, Marika Poprawska, Dariusz Sagan, Karolina Stencel, Katarzyna Szot i Piotr Wróblewski, Filozoficzne Aspekty Genezy 2011, t. 8, s. 138 [137-151], http://www.nauka-a-religia.uz.zgora.pl/images/FAG/2011.t.8/art.09.pdf (24.01.2018); Andrzej ZавоєотNY, „Naturalizm metodologiczny w nauce - dylemat teisty”, Filozoficzne Aspekty Genezy 2016, t. 13, s. 32 [25-48], http://www.nauka-a-religia.uz.zgora.pl/images/FAG/ 2016.t.13/art.09.pdf (24.01.2018); DE VRIES, „Naturalizm w naukach przyrodniczych...”, s. 122123.
} 
zwany może być naturalizmem naukowym lub metodologicznym. Należy jednak wyraźnie oddzielić naturalizm metodologiczny od naturalizmu metafizycznego. Ten ostatni bierze niepełne opisy i heurystyczne metody pierwszego albo za ostateczną prawdę na temat rzeczywistości, albo przynajmniej za granice aktualnej ludzkiej wiedzy. ${ }^{42}$

Zaś główną ideę tego naturalizmu — wyrażaną w przekonaniu, w myśl którego zjawiska tego świata wyjaśniać należy wyłącznie za pomocą verae causae, przyczyn odwołujących się jedynie do zjawisk naturalnych — przypisuje się, o czym już wspominano, Karolowi Darwinowi. ${ }^{43}$ Twierdzi się również, że największym odkryciem Darwina jest zdefiniowanie, za pomocą postulatu naturali-

\footnotetext{
${ }^{42}$ Edgar Sheffield Brightman, „An Empirical Approach to God”, The Philosophical Review 1937, vol. XLVI, no. 2, s. 157-158 [147-169], http://www.jstor.org/stable/1483003?seq=1\#page scan_tab_contents (28.01.2018). Por. też Keith B. Miller, „The Misguided Attack on Methodological Naturalism”, w: Jill S. Schneiderman and Warren D. Allmon (eds.), For the Rock Record: Geologists on Intelligent Design, University of California Press, Berkeley, Los Angeles, London 2009, s. 124 [117-140].

${ }^{43}$ Por. wypowiedź Kazimierza Jodkowskiego w: Borczyк, Chmielewski, Elżanowski, Jodkowski, Leszczyński, Lukierski, Nysler i Pawıowski, „Dyskusja...”, s. 157. Por. też Stephen Dilley, „The Evolution of Methodological Naturalism in the Origin of Species”, HOPOS: The Journal of the International Society for the History of Philosophy of Science 2013, vol. 3, no. 1, s. 20 [2058], http://www.jstor.org/stable/10.1086/667897?seq=1\#page_scan_tab_contents (23.01.2018).

Ruse utrzymuje, że verae causae wprowadził Darwin do swojej teorii dzięki Herschelowi, zaś ten ostatni mocno akcentował ich materialny charakter (por. Michael Ruse, „Darwin's Debt to Philosophy: An Examination of the Influence of the Philosophical Ideas of John F.W. Herschel and William Whewell on The Development of Charles Darwin's Theory of Evolution", Studies in History and Philosophy of Science Part A 1975, vol. 6, no. 2 s. 174-175 [159-181], http://tiny. $\mathrm{pl} / \mathrm{gkfhx}$ [08.02.2018]).
}

Według Herschela verae causae

nadają się, przy różnych modyfikacjach, do wytworzenia znacznie większej ilości skutków niż tylko tych, które doprowadziły do wiedzy o tych przyczynach. Do takich przyczyn Newton stosował termin verae causae, czyli przyczyn, których realne istnienie rozpoznaje się w przyrodzie i które nie jest czczymi hipotezami lub wymysłami umysłu.

John F.W. Herschel, Preliminary Discourse on the Study of Natural Philosophy, Longman, Brown, Green \& Longmans, London 1851, s. 144, https://archive.org/details/preliminarydisco00 hersiala (08.02.2018).

Mówiąc o Darwinowskich zapożyczeniach w sprawie verae causae nie należy zapominać o Charlesie Lyellu:

Nigdy nie zapomnę - wspominał Darwin — że wszystko to, czego dokonałem w nauce, zawdzięczam lekturze tej wspaniałej książki [Principles of Geology Lyella]. 
zmu metodologicznego, współczesnego rozumienia naukowości. ${ }^{44}$

Zdaniem niektórych to Francis Bacon jako pierwszy postulował ograniczenie nauki do wyjaśnień naturalistycznych. ${ }^{45}$ Angielski filozof pisał tak:

dokonaliśmy podziału filozofii przyrody ze względu na to, jakie przyczyny bada [...]; fizyka bada przyczyny materialną i sprawczą, zaś metafizyka przyczyny formalną i celową. ${ }^{46}$

E. Janet Browne, Charles Darwin: The Power of Place, Princeton University Press, Princeton 2003, s. 417 (cyt. za: Grzegorz Malec, „Erozja teizmu Darwina, czyli wpływ podróży na okręcie HMS Beagle na poglądy teologiczne angielskiego przyrodnika", w: Krzysztof BAŁĘKOWSKI i Kamil MACiĄG (red.), Wybrane zagadnienia z filozofii języka i religii, Fundacja na rzecz promocji nauki i rozwoju TYGIEL, Lublin 2015, s. 116 [110-120], www.nauka-a-religia.uz.zgora.pl/ images/Przedruki/Malec_Erozja.teizmu.Darwina.pdf [08.02.2018]).

W Principles of Geology Lyell, za Jamesem Huttonem, utrzymywał, że należy

całkowicie obywać się bez hipotetycznych przyczyn i wyjaśniać wcześniejsze zmiany skorupy ziemskiej wyłącznie za pomocą czynników naturalnych [natural agents] [...] tak samo, jak zrobił to Newton w astronomii.

Charles Lyell, Principles of Geology or, the Modern Changes of the Earth and its Inhabitants Considered as Illustrative of Geology, D. Appleton \& Co., New York 1854, s. 50-51, https://archive.org/details/principlesofgeol00lyelrich (19.01.2018).

Darwin podjął podobną decyzję, z tą różnicą, że dokonał ekstrapolacji poglądu Lyella. Darwin zrezygnował z odwołań do przyczyn nadnaturalistycznych nie tylko na gruncie geologii, ale całej historii naturalnej.

Malec, „Erozja teizmu Darwina...”, s. 116. Por. też Dilley, „The Evolution of Methodological Naturalism...", s. 25-26.

${ }^{44}$ Por. JodKowski, „Antynaturalizm teorii inteligentnego projektu...”, s. 63.

Antycypację poglądu Jodkowskiego odnaleźć można u Juliana Huxleya, który w 1959 roku, na wystąpieniu z okazji setnej rocznicy wydania The Origin of Species, w University of Chicago powiedział tak:

Rzeczywistym osiągnięciem Darwina było usunięcie całej idei Boga jako stworzyciela organizmów ze sfery racjonalnej dyskusji.

Cyt. za: Russell Grigg, „Tajemnicza choroba Darwina”, przeł. Andrew Ostapowicz, Creation Ministries International, http://creation.com/darwins-mystery-illness-polish (17.01.2018). Por. też Randal Hedtke, Secrets of the Sixth Edition: Darwin Discredits His Own Theory, Master 
Bacon utrzymywał również, że wyjaśnienia fizyki nie mają charakteru ostatecznego:

historia naturalna bada i łączy fakty, zaś fizyka bada ich zmienne [...] przyczyny materialne i sprawcze ${ }^{47}$

oraz że posługiwanie się przyczynami celowymi w fizyce jest szkodliwe, bowiem „wypiera poszukiwania przyczyn fizycznych”. ${ }^{48}$

Twierdzi się także, że

przed wiekiem dziewiętnastym był on [naturalizm metodologiczny] łączony z fizyką, dla której, jak się zdaje, jest najstosowniejszy. Jednakże bujny rozwój filozoficznego naturalizmu w wieku dziewiętnastym umożliwił wprowadzenie metodologicznego naturalizmu do nauk, które uprzednio go nie zawierały. Darwin wprowadził naturalizm metodologiczny do biologii, Freud do psychologii, a Marks do ekonomii. ${ }^{49}$

Books, Green Forest 2010, s. 136.

${ }^{45}$ Por. Michael Ruse, „The Argument from Design: A Brief History”, w: William A. Dembsk and Michael Ruse (eds.), Debating Design: From Darwin to DNA, Cambridge University Press, Cambridge 2004, s. 16 [13-31], https://www.researchgate.net/publication/285439477 The Argu ment_from_Design_A_Brief_History (19.01.2018); James C. LEMASTER, „The Relationship of Bacon, Teleology, and Analogy to the Doctrine of Methodological Naturalism", w: BARTLETT and Holloway (eds.), Naturalism and Its Alternatives..., s. 68 [67-89]; istnieje też polski przekład tego tekstu: James C. LeMASTER, „Związek między Baconem, teleologią i analogią a doktryną naturalizmu metodologicznego", przeł. Dariusz Sagan, Filozoficzne Aspekty Genezy 2017, t. 14, s. 99-133, http://www.nauka-a-religia.uz.zgora.pl/images/FAG/2017.t.14/art.04.pdf (10.03.2018).

Podobną opinię wyraził też Dembski:

Naukę, wedle Bacona, należy ograniczyć do przyczyny materialnej i formalnej, co uwalnia ją od jałowości, która jest nieuchronną konsekwencją połączenia nauki z metafizyką.

William A. Dembski, „Powrót projektu do nauk przyrodniczych”, przeł. Dariusz Sagan, $\mathrm{Na}$ Poczatku... 2004, nr 9-10 (185-186), s. 325 [323-342], www.nauka-a-religia.uz.zgora.pl/images/ Przedruki/Dembski_Powrot.projektu.pdf (22.01.2018).

${ }^{46}$ Francis BACon, The Advancement of Learning, P.F. Collier and Son, New York 1901, s. 147-148, http://oll.libertyfund.org/titles/bacon-the-advancement-of-learning (20.01.2018).

${ }^{47}$ BACON, The Advancement of Learning..., s. 149.

${ }^{48}$ BACON, The Advancement of Learning..., s. 165.

${ }^{49}$ Jonathan Bartlett and Eric Holloway, „Introduction”, w: Bartlett and Holloway (eds.), Naturalism and Its Alternatives..., s. 1 [1-9]. Por. też Phil StILwell, „The Status of Methodologi- 
Takie mocne łączenie naturalizmu metodologicznego z fizyką jest nietrafne. ${ }^{50}$ Newton, jak powszechnie wiadomo, dopuszczał w fizyce wyjaśnienia nadnaturalistyczne. Naturalizm ten w pełni zaczął funkcjonować dopiero wraz z opublikowaniem $O$ powstawaniu gatunków Darwina. ${ }^{51}$

Naturalizm metodologiczny ma trzy podstawowe źródła: mechanicystyczną filozofię osiemnastego stulecia, która dostarczyła mu ontologii (istnieje jedynie materia i ruch); XIX-wieczną filozofię pozytywistyczną, która dostarczyła mu epistemologii (sensowne są tylko te zdania, które mówią o materii i ruchu) oraz teologię, która wyłączyła refleksję o Bogu z racjonalnego dyskursu. Teologia lansowała ideę niepoznawalności Boga, zgodnie z którą Bóg przekracza wszystko, co jesteśmy w stanie zrozumieć i wyrazić za pomocą języka, którym opisujemy świat realny:

Bo myśli moje nie są myślami waszymi ani wasze drogi moimi drogami [...]. Bo jak niebiosa górują nad ziemią, tak drogi moje — nad waszymi drogami i myśli moje nad myślami waszymi (Iz 55:8-9 [BT]).

Możemy jedynie rozpatrywać Jego przymioty w kategoriach aksjologicznych lub posługiwać się metaforami. ${ }^{52}$

Nakaz ograniczania badań naukowych do świata przyrody nazywany jest

cal Naturalism as Justified by Precedent", Studies in Liberal Arts and Sciences 2009, no. 41, s. 233-234 [229-247].

${ }^{50}$ Por. np. Robert C. Bishop, „God and Methodological Naturalism in the Scientific Revolution and Beyond", Perspectives on Science and Christian Faith 2013, vol. 65, no. 1, s. 14-16 [1023], https://www.researchgate.net/publication/260779528_God_and_Methodological_Naturalism in the Scientific Revolution and Beyond (24.01.2018); Paul NeLson, „Methodological Naturalism: A Rule That No One Needs or Obeys", Evolution News and Science Today 22 September 2014, https://evolutionnews.org/2014/09/methodological_1/ (02.01.2018).

${ }^{51}$ Por. np. JodKowsKI, „Konflikt nauka-religia...”, s. 160-161; JodKowsKI, „Antynaturalizm teorii inteligentnego projektu...”, s. 63-64; Piotr ByLICA, „Darwin o celowości w przyrodzie”, Kwartalnik Historii Nauki i Techniki 2008, R. 53, nr 3-4, s. 269 [259-273], http://www.nauka-areligia.uz.zgora.pl/images/Przedruki/Bylica Darwin.o.celowosci.w.przyrodzie.pdf (20.01.2018); Grzegorz MALEC, „Naturalizm metodologiczny w sporze ewolucjonizmu z kreacjonizmem w świetle poglądów Paula K. Feyerabenda", Filozoficzne Aspekty Genezy 2012, t. 9, s. 132-135 [131-154], http://www.nauka-a-religia.uz.zgora.pl/images/FAG/2012.t.9/art.12.pdf (20.01.2018).

${ }^{52}$ Por. Bartlett, „Filozoficzne wady naturalizmu metodologicznego...”, s. 60-61, 75-81. 
również: „standardowym ujęciem” (the standard view) praktyki naukowej; ${ }^{53}$ „mocnym naturalizmem metodologicznym” (,jedynym prawowitym źródłem wiedzy o świecie przyrody są nauki przyrodnicze”); ${ }^{54}$,metodologicznym ateizmem" ${ }^{55}$ (działanie Boga lub każdej innej przyczyny nienaturalnej wykluczone jest z badania naukowego); ${ }^{56}$ „,metodologicznym a-teizmem”; ${ }^{57}$ „prowizorycznym ateizmem”; 58 „metodologicznym agnostycyzmem”; ${ }^{59}$ „reguła nauki” (rule of science) („która wymaga, aby w wyjaśnieniach naukowych stosować jedynie

\footnotetext{
${ }^{53}$ Por. Dilley, „The Evolution of Methodological Naturalism...”, s. 20.

${ }^{54}$ Por. McMuldin, „Odmiany naturalizmu metodologicznego...”, s. 111.

${ }^{55}$ Por. Nancey Murphy, „Phillip Johnson on Trial: A Critique of His Critique of Darwin”,
} Perspectives on Science and Christian Faith 1993, vol. 45, no. 1, s. 26-36, http://www.asa3.org/ ASA/PSCF/1993/PSCF3-93Murphy.html (17.02.2018); Bruce L. Gordon, „W obronie uniformitaryzmu”, przeł. Agnieszka Biesiadecka, Dorota Brylla, Małgorzata Gazda, Grzegorz Malec, Radosław Plato, Maciej Powąska, Alicja Ratajczak i Dariusz Sagan, Filozoficzne Aspekty Genezy 2014, t. 11, s. 140 [133-149], http://www.nauka-a-religia.uz.zgora.pl/images/FAG/2014.t.11/art.05.pdf (17.02.2018); JoDKowsKI, Metodologiczne aspekty..., s. 293.

${ }^{56}$ Por. Charles Hodge, What Is Darwinism?, Scribner, Armstrong and Company, New York 1874, s. 122, https://ia600201.us.archive.org/10/items/cu31924024755567/cu31924024755567. pdf (17.02.2018). Por. też JodKowski, „Twarde jądro ewolucjonizmu...”, s. 91; Grzegorz MALEC, „«Wzniosły jest pogląd, że Stwórca...», czyli łapówka Darwina dla chrześcijan”, Filozoficzne Aspekty Genezy 2014, t. 11, s. 190 przyp. 11 [187-204], http://www.nauka-a-religia.uz.zgora.pl/ images/FAG/2014.t.11/art.09.pdf (17.01.2018); Michał ChABEReK OP, „Św. Tomasz z Akwinu a ewolucjonizm. Polemika z tezami Piotra Lichacza OP i Williama E. Carrolla”, Filozoficzne Aspekty Genezy 2012, t. 9, s. 37 [33-52], http://www.nauka-a-religia.uz.zgora.pl/images/FAG/ 2012.t.9/art.01.pdf (18.01.2018); Karl W. GiBERSON i Donald A. YeRXA, O gatunkach powstawania. W poszukiwaniu opowieści o stworzeniu, przeł. Dariusz Sagan, Biblioteka Filozoficznych Aspektów Genezy, t. 3, Wydawnictwo MEGAS, Warszawa 2008, s. 20; Ров i MүтYк, „Od metody naukowej do naturalizmu metodologicznego...", s. 140.

${ }^{57}$ Tak też można nazwać ten nakaz, wykorzystując następującą wypowiedź Michała Hellera:

Kreseczka jest tutaj istotna. Wskazuje ona, że metoda naukowa nie nakazuje zakładać, iż Boga nie ma, lecz żąda, by prowadząc badanie naukowe, zachować metodologiczną neutralność wobec problemu Jego istnienia lub nieistnienia.

Michał Heller, Sens życia i sens Wszechświata. Studia z teologii wspólczesnej, Biblos, Tarnów 2002, s. 45. Por. też Piotr ByLICA, „Nauka światopoglądowo neutralna...”, s. 71.

${ }^{58}$ Por. Alvin Plantinga, „Naturalizm metodologiczny?”, przeł. Radosław Plato, Filozoficzne Aspekty Genezy 2014, t. 11, s. 39 [37-93], http://www.nauka-a-religia.uz.zgora.pl/images/FAG/ 2014.t.11/art.03.pdf (15.01.2018); Ров i МүтYк, „Od metody naukowej do naturalizmu metodologicznego...”, s. 140; Јоркошккі, Metodologiczne aspekty..., s. 292. 
materialne przyczyny”); ${ }^{60}$ „powszechnie przyjętą konwencją”; ${ }^{61}$ „ekskluzywnym naturalizmem" (exclusive naturalism) (milcząco uznającym wszystkie sądy o istnieniu bytów nadprzyrodzonych za zdania fałszywe). ${ }^{62}$ Ekskluzywizm ten bazuje na następującym przekonaniu:

nauka zapewnia [...] możliwość zrozumienia rzeczywistości właśnie wówczas, gdy jest ograniczona naturalizmem metodologicznym. ${ }^{63}$

Naturalistyczny EUO uznawany jest za „teorię-matkę wszystkich nauk przyrodniczych", za paradygmat tego, jak należy uprawiać naukę. ${ }^{64}$ Świadczy o tym na przykład taka opinia:

\footnotetext{
${ }^{59}$ Por. Douglas V. Porpora, „Methodological Atheism, Methodological Agnosticism and Religious Experience", Journal for the Theory of Social Behaviour 2006, vol. 36, no. 1, s. 57-58 [5775], https://www.researchgate.net/publication/229640920_Methodological_Atheism_Methodolog ical_Agnosticism_and_Religious_Experience (20.01.2018).

${ }^{60}$ Por. Eugenie C. Sсотт, Evolution vs. Creationism. An Introduction. Second Edition, Greenwood Press, Westport, Connecticut, London 2009, s. 56.

${ }^{61}$ Por. Tomasz Krause, „Filozoficzne aspekty tzw. «afery Kansas»”, Filozoficzne Aspekty Genezy 2004, t. 1, s. 143 [143-224], www.nauka-a-religia.uz.zgora.pl/images/FAG/2004.t.1/art. 08.pdf (03.02.2018). Por. też Erkki V.R. KoJonen, „Methodological Naturalism and the Truth Seeking Objection", International Journal for Philosophy of Religion 2016, vol. 79, no. 3, s. 4 [126], http://blogs.helsinki.fi/ekojonen/files/2015/10/Methodological-naturalism-and-the-truth-seeking-objection-Kojonen-1.pdf (18.01.2018).

${ }^{62}$ Por. Scott F. Aikin, Michael Harbour, and Robert B. TAlisse, „Nagel on Public Education and Intelligent Design", Journal of Philosophical Research 2010, vol. 35, s. 211 [209-219], http://tiny.pl/gkfh3 (01.01.2018).

W świetle innego ujęcia takie stanowisko nazywane jest również „materialistycznym ewolucjonizmem" (,żaden czynnik nadprzyrodzony nie istnieje, [...] przyroda i jej prawa są wszystkim, co jest”) (por. Kazimierz Jodkowski, „Klasyfikacja stanowisk kreacjonistycznych”, Filozoficzne Aspekty Genezy 2005/2006, t. 2/3, s. 254-255 [241-269], www.nauka-a-religia.uz.zgora.pl/images/ FAG/2005-2006.t.2-3/art.11.pdf [02.02.2018]).

${ }^{63}$ Robert C. O'Connor, „Science on Trial: Exploring the Rationality of Methodological Naturalism", Perspectives on Science and Christian Faith 1994, vol. 49, no. 1, s. 15-31, http://www. asa3.org/ASA/PSCF/1997/PSCF3-97OConnor.html (16.01.2018); istnieje też polski przekład tego tekstu: Robert C. O'ConNoR, „Nauka przed sądem: analiza racjonalności naturalizmu metodologicznego", przeł. Joanna Popek i Grzegorz Rogula, Filozoficzne Aspekty Genezy 2014, t. 11, s. 97 [95-131], http://www.nauka-a-religia.uz.zgora.pl/images/FAG/2014.t.11/art.04.pdf (16.01.2018). Przywoływany autor nie formułuje explicite treści tej zasady. Por. też William A. Dembski, „Odmiany naturalizmu. Czy któraś forma naturalizmu jest zgodna z teorią inteligentnego projektu?", przeł. Dariusz Sagan, Na Poczatku ... 2005, R. 13, nr 1-2, s. 46 [45-54], www.nauka-a-religia.uz. zgora.pl/images/Przedruki/Dembski_Odmiany.naturalizmu.pdf (22.01.2018).
} 
chociaż nauka może uzasadnić fałszywość hipotezy projektu, to żadne świadectwa wymierzone $\mathrm{w}$ to uzasadnienie nie mogą być uznawane za naukowe. ${ }^{65}$

Naturalistyczne podejście do problemu powstawania życia (stanowiące, zdaniem niektórych, ,jądro filozofii humanistycznej” ${ }^{66}$ ) określone nawet zostało mianami „darwinowskiego układu odniesienia” ${ }^{77}$ (Darwinian frame of reference) i „tezy o ślepym zegarmistrzu”. ${ }^{68}$ Pojawiła się także nazwa „historyczny układ odniesienia ewolucjonizmu" (historical framework of evolution) dla ozna-

\footnotetext{
${ }^{64}$ Por. Kazimierz Jodkowski, „Spisek Darwina”, w: LeszczyŃski (red.), Ewolucja, filozofia, religia..., s. 276 [265-277], www.nauka-a-religia.uz.zgora.pl/images/Przedruki/Jodkowski_Spis ek.Darwina.pdf (31.01.2018); JodKowskI, „Eskapizm teologii i filozofii katolickiej...”, s. 273-274; Kazimierz Jоркоwsкi, „Darwinowska teoria ewolucji jako teoria filozoficzna”, w: Stefan KoNstaŃCZAK i Tomasz Turowski (red.), Filozofia jako mądrość bycia. Profesorowi Krzysztofowi Kaszyńskiemu w darze z okazji 70. urodzin, Oficyna Wydawnicza Uniwersytetu Zielonogórskiego, Zielona Góra 2009, s. 22 [17-23], www.nauka-a-religia.uz.zgora.pl/images/Przedruki/Jodkowski Darwinowska.teoria.ewolucji.jako.teoria.filozoficzna.pdf (31.01.2018); JоркоwsкI, „Nienaukowy fundament nauki...”, s. 100-101; JoDKowsKI, „Epistemiczny układ odniesienia teorii inteligentnego projektu...", s. 97.

${ }^{65}$ Por. NAGeL, „Public Education and Intelligent Design...”, s. 189. Mimo tego, że wypowiedź ta sformułowana została przez jednego z krytyków obstawania przy naturalizmie metodologicznym za wszelką cenę, to znakomicie oddaje przekonanie o hegemonii wyjaśnień naturalistycznych.

${ }^{6}$ Por. Henry M. Morris, „Evolution Is Religion - Not Science”, Acts \& Facts 2001, vol. 30, no. 2, https://www.icr.org/article/455 (17.02.2018).

${ }^{67}$ Por. Percival Davis and Dean H. Kenyon, Of Pandas and People: The Central Question of Biological Origins, Foundation for Thought and Ethics, Richardson, Texas 1993, s. viii. Krytycznie nastawiony do darwinowskiego ewolucjonizmu, Pierre Grassé istotę owego układu przedstawiał tak:

przyroda działa ślepo, nieinteligentnie, ale poprzez nieskończenie życzliwe szczęście buduje mechanizmy tak zawiłe, że nie potrafiliśmy nawet dokonać pełnej analizy ich struktury i nie mamy najmniejszego wglądu w zasady fizyczne i funkcjonowanie niektórych z nich.

Pierre P. Grassé, Evolution of Living Organisms: Evidence for a New Theory of Transformation, Academic Press Inc., New York 1977, s. 208. Fragment w przekładzie Kazimierza Jodkowskiego: Phillip E. Johnson, „Reguły rozumowania darwinizmu”, w: Jodkowski, Metodologiczne aspekty..., s. 462 [460-472].

${ }^{68}$ Określenia tego użył Phillip E. Johnson, Reason in the Balance: The Case Against Naturalism in Science, Law \& Education, InterVarsity Press, Downers Grove 1995, s. 14. Por. też Phillip E. Johnson, „Głośna herezja w świątyni Darwina”, przeł. Kazimierz Jodkowski, w: JoDKowsKi, Metodologiczne aspekty..., s. 478 [473-481]; Piotr BYLICA, „Konflikt między teizmem
} 
czenia dominacji naturalistycznych wyjaśnień w biologii. ${ }^{69}$

De facto antynadnaturalistyczne i antyartyficjalistyczne odmiany naturalizmu metodologicznego są jednymi z możliwych i praktykowanych EUO. ${ }^{70}$ Dwa inne antynaturalistyczne EUO, funkcjonujące w swej obecnej postaci, ukształtowały się w trakcie dyskusji z metodologicznym naturalizmem. ${ }^{71}$

EUO naturalizmu antynadnaturalistycznego scharakteryzować można w następujący sposób. Przyczynom naturalnym przeciwstawia się tu przyczyny nad-

i nauką bazująca na naturalizmie - w ujęciu Phillipa E. Johnsona", Zagadnienia Naukoznawstwa 2003, nr 3-4 (157-158), s. 230 [227-238], www.nauka-a-religia.uz.zgora.pl/images/Przedruki/Byli ca Konflikt.miedzy.teizmem.i.nauka.pdf (06.02.2018); Dariusz SAGAN, „Teoria inteligentnego projektu a ewolucjonizm”, Kwartalnik Filozoficzny 2013, t. XLI, z. 2, s. 79 [75-96], www.naukaa-religia.uz.zgora.pl/images/Przedruki/Sagan Teoria.ID.a.ewolucjonizm.pdf (17.02.2018); Kazimierz JoDKоwski, „Rodzaje procesu ewolucyjnego i sens przypadku. Wyjaśnianie nieporozumień — ciag dalszy", Filozofia Nauki 2006, nr 1 (53), s. 174 [169-174], www.nauka-a-religia.uz.zgora. pl/images/Przedruki/Jodkowski_Rodzaje.procesu.ewolucyjnego.pdf (14.02.2018); Richard DAWKINS, Ślepy zegarmistrz, czyli jak ewolucja dowodzi, że świat nie zostal zaplanowany, przeł. Antoni Hoffman, Biblioteka Myśli Współczesnej, Państwowy Instytut Wydawniczy, Warszawa 1994, s. 27.

${ }^{69}$ Por. Jonathan Bartlett and Eric Holloway, „Other Non-Naturalistic Methodologies in Modern Practice”, w: Bartlett and Holloway (eds.), Naturalism and Its Alternatives..., s. 264 [257-268]; istnieje też polski przekład tego tekstu: Jonathan BartletT and Eric HollowaY, „Nienaturalistyczne metodologie we współczesnej praktyce”, przeł. Dariusz Sagan, Filozoficzne Aspekty Genezy 2016, t. 13, s. 101-117, http:/www.nauka-a-religia.uz.zgora.pl/images/FAG/2016.t.13/art. 08.pdf (10.03.2018).

${ }^{70}$ Por. JodKowsKi, „Nienaukowy fundament nauki...”, s. 96; JoDKowski, „Epistemiczne układy odniesienia...”, s. 116; wypowiedź Kazimierza Jodkowskiego w: Radosław Kopeć i Paweł Снолескі, „Wywiad z prof. Jodkowskim”, Idź Pod Prad 2007, nr 11 (40), s. 11 [8 i 11], www.na uka-a-religia.uz.zgora.pl/images/Przedruki/Kopec.Chojecki_Wywiad.z.prof.Jodkowskim.pdf (15.

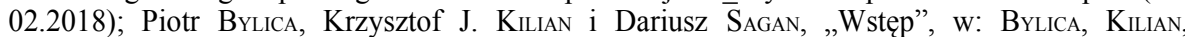
PIotrowski i SAGAN (red.), Filozofia — nauka - religia..., s. 18 [11-33], http://www.nauka-a-reli gia.uz.zgora.pl/images/Przedruki/Filozofia.nauka.religia.pdf (31.01.2018); ByLICA, Wspólczesny teizm naturalistyczny..., s. 28; Robert Ріотвошsкі, „Kulturowe a filozoficzne tho neokreacjonizmu amerykańskiego", w: JoDKOWSKI (red.), Teoria inteligentnego projektu..., s. 26 [25-50].

${ }^{71}$ Istnieje jeszcze jeden, dokładnie opisany przez Piotra Bylicę, epistemiczny układ odniesienia: EUO teizmu naturalistycznego. Ten EUO wykracza poza sferę samej nauki i jest na tyle rozległym i interesującym problemem, że wymaga oddzielnych analiz. W tym miejscu pokrótce nakreślę jedynie sedno tego podejścia. Naturalizm metodologiczny oraz, omówieni w dalszej części tego paragrafu, jego kontrpretendenci do elementarnego ujęcia praktyki naukowej, za pomocą sformułowanych w swoich ramach koniecznych warunków naukowości, tworzą najogólniejsze ramy dla uprawiania nauki. Zaś EUO naturalistycznego teizmu tworzy inną, specyficzną ramę jej uprawiania. Nie tylko proponuje najogólniejsze ramy uprawiania nauki. Dąży również do zaże- 
przyrodzone (nadnaturalne). W ramach tego podejścia nakaz przyjmowania wyjaśnień naturalistycznych uzupełniony został o, nazwany „zasadą ekskluzji” (principle of exclusivity), ${ }^{72}$ zakaz przyjmowania wyjaśnień powołujących się na przyczyny nadnaturalne.

$\mathrm{Z}$ nakazem ograniczania badań jedynie do świata przyrody idzie w parze mocna metafizyczna teza, określana jako „twarde jądro”, gdyż zwolennicy tego ujęcia „nigdy go nie porzucą i zawsze go będą bronić”. Zgodnie z tą tezą:

Boga nie ma, albo jeśli jest, to nie działa w przyrodzie w bezpośredni sposób. ${ }^{73}$

gnania kryzysu wiary wśród ludzi wykształconych, w szczególności naukowców. Kryzys ten jest następstwem niezgodności tradycyjnego teistycznego oraz współczesnego, bazującego na naturalizmie metodologicznym, naukowego opisu świata. Innym celem sformułowania tego EUO jest próba obrony cywilizacji chrześcijańskiej przed usiłowaniami przekształcenia jej w cywilizację postchrześcijańską. Obrona ta odbywać ma się drogą pogodzenia obrazu świata współczesnego przyrodoznawstwa z teizmem chrześcijańskim. (De facto chodzi tu o pogodzenie naturalizmu metodologicznego z tą wersją teizmu.) Zarówno zażegnanie kryzysu wiary, jak i godzenie obrazu świata przyrodoznawstwa z teizmem odbywa się drogą „umiejętnego czytania” ksiąg Pisma Świętego. Zaś takie czytanie ma olbrzymie koszty światopoglądowe i epistemiczne. Sprowadzają się one, najogólniej rzecz biorąc, do dostosowywania twierdzeń teologicznych do naukowego naturalizmu, co bardzo często prowadzi do poważnej reinterpretacji podstawowych elementów tradycyjnej wiary chrześcijańskiej (por. np. Piotr ByLICA, „Mark Harris as a Naturalistic Theist: The Perspective of the Model of Levels of Analysis", Filozoficzne Aspekty Genezy 2015, t. 12, s. 8-9 [736], http://www.nauka-a-religia.uz.zgora.pl/images/FAG/2015.t.12/art.11.pdf [14.02.2018]; ByLICA, „Kazimierza Jodkowskiego koncepcja epistemicznych układów odniesienia...”, s. 192-193; BYLICA, „Nauka światopoglądowo neutralna...”, s. 75-76; BYLICA, Współczesny teizm naturalistyczny..., s. 152-153; BYLICA, „Główne założenia i problemy teizmu naturalistycznego...”, s. 8889).

${ }^{72}$ Por. O’CONnoR, ,Science on Trial...”; O’Connor, „Nauka przed sądem...”, s. 97.

${ }^{73}$ Por. Jodкоwsкi, „Darwinowska teoria ewolucji jako teoria filozoficzna...”, s. 19; JoDKowsкI, „Metafizyczne opowieści nauki...”, s. 79; JoDKOwSKI, „Twarde jądro ewolucjonizmu...”, s. 82-83; JodKowsKI, „Filozoficzna natura sporu ewolucjonizm-kreacjonizm...”; JodKowsKI, „Uczony w ciemnym budynku...”, s. 60; BYLICA, „Główne założenia i problemy teizmu naturalistycznego...”, s. 63; BYLICA, „Naturalizm metodologiczny jako warunek naukowości...”, s. 165; Bylica, „Zaburzenia dysocjacyjne czy opętanie przez Szatana...”, s. 218-219; Dariusz SAGAN, „Teoria inteligentnego projektu - argumenty za i przeciw”, w: Stanisław JANECZEK, Anna STArościc, Dariusz DĄBEK i Justyna Herda (red.), Filozofia przyrody, Dydaktyka Filozofii, t. III, Wydawnictwo Katolickiego Uniwersytetu Lubelskiego, Lublin 2013, s. 342-343 [335-383], www. nauka-a-religia.uz.zgora.pl/images/Przedruki/Sagan_Teoria.ID.argumenty.za.i.przeciw.pdf (10.02 . 2018); Dariusz SAGAN, „Zdolność przewidywania jak̄o warunek naukowości w sporze o ewolucję i inteligentny projekt", Zagadnienia Naukoznawstwa 2012, nr 4 (194), s. 278 [269-286], www.nau ka-a-religia.uz.zgora.pl/images/Przedruki/Sagan_Zdolnosc.przewidywania.pdf (17.02.2018); RATzsCH, „Teologia naturalna, naturalizm metodologiczny...”, s. 17; PoE i Мүтүк, „Od metody nauko- 
Wedle nadnaturalistycznego EUO (kojarzonego z kreacjonizmem nadnaturalistycznego interwencjonizmu ${ }^{74}$ ) w wyjaśnianiu zjawisk przyrodniczych obok przyczyn naturalnych dopuszczać należy przyczyny nadnaturalne - interwencję bytu nadprzyrodzonego, czyli Boga. ${ }^{75}$ Nakaz taki nazywany jest też „zasadą inkluzji” (principle of inclusivity). ${ }^{76} \mathrm{~W}$ myśl tej zasady

wyjaśnienia mówiące o bezpośrednim działaniu boskiego sprawcy mogą stanowić właściwą część nauk przyrodniczych. ${ }^{77}$

Przyjęcie tej zasady nie oznacza, że postuluje się tu badanie sfery nadprzyrodzonej:

Odrzucanie kreacjonizmu jako poglądu nienaukowego najczęściej polega na intuicyjnym stosowaniu następującego rozumowania: nauka zajmuje się tylko tym, co jest naturalne, lub z przyczyn naturalnych wynika (ontologiczny naturalizm), jeśli więc ktoś zakłada przyczyny ponadnaturalne tym samym dyskwalifikuje swoje poglądy jako nienaukowe. Ten sposób myślenia, reprezentowany przez ogromną większość ewolucjonistów i w ogóle przyrodników, wyznacza swoiste potoczne kryterium demarkacji [...] między nauką i nie-nauką $[\ldots] .^{78}$

Nadnaturalistyczny interwencjonizm

wej do naturalizmu metodologicznego...”, s. 142; MeYER, „Demarkacja nauki i religii...”, s. 181; NAGEL, „Public Education and Intelligent Design...”, s. 205.

Tak rozumiane twarde jądro, jako twierdzenie o jawnie nieempirycznym charakterze, odróżniane bywa od empirycznego twardego jądra, na które składają się testowalne twierdzenia, z któ rych ich zwolennicy nigdy by nie zrezygnowali (por. np. Kazimierz JoDKowski, „W poszukiwaniu twardego jądra ewolucjonizmu”, Filozofia Nauki 2001, nr 2 (34), s. 18 [7-18], http://tiny.pl/xh81h [31.01.2018]; JoDKOwSKI, „Twarde jądro ewolucjonizmu...”, s. 83-84).

${ }^{74}$ Por. JodKowski, „Rozpoznawanie genezy...”, s. 188.

${ }^{75}$ Por. np. Jodkowski, „Nienaukowy fundament nauki...”, s. 100-103; Robert T. PenNock, „Bóg w lukach wiedzy: argument z niewiedzy i ograniczenia naturalizmu metodologicznego”, przeł. Dariusz Sagan, Filozoficzne Aspekty Genezy 2012, t. 9, s. 156 [155-185], http://www.nauka -a-religia.uz.zgora.pl/images/FAG/2012.t.9/art.04.pdf (20.01.2018).

${ }^{76}$ Por. O’Connor, „Science on Trial...”, s. 15; O’Connor, „Nauka przed sądem...”, s. 95.

${ }^{77}$ O'CONnOR, „Nauka przed sądem...”, s. 95.

${ }^{78}$ Grzegorz NowaK, „Książka filozofa o sporze między ewolucjonistami i kreacjonistami”, Filozofia Nauki 2001, t. 9, nr 2, s. 162-163 przyp. 2 [161-168]. 
ma [zatem] za przedmiot ten sam świat materialny, o jakim mówią teorie, co do których nie ma wątpliwości, że są naukowe. ${ }^{79}$

Przykładów świadczących o zasadności tej tezy jest wiele. W tym miejscu ograniczę się do przedstawienia dwóch. Młodoziemscy kreacjoniści, gdy chcą uzasadnić tezę o młodym wieku Ziemi, zastanawiają się, w jakim stopniu wiarygodne są metody datowania radioaktywnego ${ }^{80}$ lub prowadzą badania nad zmiennym tempem poruszania się ziemskich płyt tektonicznych. ${ }^{81}$

Twarde jądro nadnaturalizmu można sformułować tak: Bóg istnieje i działa w przyrodzie w bezpośredni sposób, ${ }^{82}$ zaś

życie [...] jest unikalnym dziełem okresu stworzenia. Stworzenie dokonało się na mocy unikalnych procesów dziś już nie występujących. ${ }^{83}$

${ }^{79}$ Por. JodKowski, „Rozpoznawanie genezy...”, s. 190.

${ }^{80}$ Por. np. Randy IsAac, „Assessing the RATE Project”, Perspectives on Science and Christian Faith 2007, vol. 59, no. 2, s. 143-146, http://www.asa3.org/ASA/education/origins/rate-ri. htm (03.02.2018); Marta CuBERBILLER, „O metodach datowania radioaktywnego”, w: GaZDA (red.), Idź Pod Prąd w sporze ewolucjonizm-kreacjonizm..., s. 230-233.

${ }^{81}$ Przykładem tych ostatnich badań są prace kreacjonisty, geofizyka i eksperta w projektowaniu komputerowych modeli konwekcji geofizycznej z Los Alamos National Labolatory, Johna R. Baumgardnera. Utrzymuje on pogląd, że pokrywające ziemię płyty geologiczne mogły się kiedyś poruszać tysiące razy szybciej niż obecnie. Jeśli tak było, to w stosunkowo niewielkim okresie czasu mogły zajść duże zmiany geologiczne, co uzasadniałoby część młodoziemskich poglądów kreacjonistycznych (por. JоркоwSкI, Metodologiczne aspekty..., s. 242-243). W przywoływanej pracy odnaleźć można więcej takich ilustracji.

${ }^{82} \mathrm{~W}$ ramach tego podejścia wyróżnia się interwencje mocne (niezgodne z prawami przyrody) i słabe, czyli zgodne z prawami przyrody. Te pierwsze to cudy (por. JoDKowskI, „Nienaukowy fundament nauki...”, s. 100-103; Kazimierz JodKowski, „Noma, cudy i filtr eksplanacyjny”, Roczniki Filozoficzne 2005, t. 53, nr 2, s. 91-92 [83-103], http://publikacje.uz.zgora.pl:7777/skep/docs/ F23001/Jodkowski,\%20NOMA\%20cudy\%20i\%20filtr\%20eksplanacyjny.doc [13.02.2018]; JoDKowsкI, „Zasadnicza nierozstrzygalność...”, s. 218; JoDKowsKI, „Epistemiczny układ odniesienia...", s. 97-98).

${ }^{83}$ Henry M. Morris, Scientific Creationism, Creation-Life Publishers, San Diego 1974, s. 46. Fragment w przekładzie JodKowsKIEGO, „Ruch kreacjonistyczny jest elementem pluralizmu naukowego...", s. 245.

W podobny sposób ideę tę wyraził Duane Gish:

Nie wiemy nic o tym, w jaki sposób działał Stwórca [i] jakich procesów użył, [ponieważ] użył takich procesów, które obecnie nigdzie nie zachodza we Wszechświecie. Właśnie dlatego mówimy o stworzeniu, jako o specjalnym stworzeniu. Badania naukowe nie powiedzą nam niczego o zastosowanych przez Stwórcę procesach stwórczych. 
Charakterystykę EUO naturalizmu antyartyficjalistycznego poprzedzić warto następującą wypowiedzią Michaela Behe'ego, gdyż trafnie oddaje ona sedno kreślonej teraz kontrowersji:

prawdziwy podział [uczonych] powinien przebiegać pomiędzy uznającymi, że istnieje celowość w świecie i w organizmach żywych, oraz takimi, którzy uważają, że jej nie ma. ${ }^{84}$

EUO naturalizmu antyartyficjalistycznego to nakaz przyjmowania wyłącznie wyjaśnień odwołujących się do „przyczyn naturalnych”, któremu towarzyszy zakaz dopuszczania wyjaśnień przez przyczyny inteligentne i celowe. ${ }^{85}$ Przyczynom naturalnym przeciwstawia się tu zatem przyczyny inteligentne (sztuczne). ${ }^{86}$

Twarde jądro EUO naturalizmu antyartyficjalistycznego brzmi tak:

na przebieg zdarzeń we Wszechświecie nie wpływa żaden inteligentny czynnik. ${ }^{87}$ S. 40 .

Duane Gish, Evolution: The Fossils Say No, Creation-Life Publishers, San Diego 1978,

${ }^{84}$ Wypowiedź Behe'ego w: Michał СнавеRек OP, „Świat jest zbyt złożony, by powstał przypadkowo. Rozmowa z Michaelem Behe'em”, Fronda 2012, nr 63, s. 39 [34-41].

${ }^{85}$ Por. Marshall Berman, ,Intelligent Design Creationism: A Threat to Society — Not Just Biology”, The American Biology Teacher 2003, vol. 65, no. 9, s. 646 przyp. 1 [646-648].

${ }^{86}$ Podobnie sprawę ujmują zwolennicy ID. Gdy ci ostatni występują przeciwko naturalizmowi metodologicznemu, to przez ten ostatni rozumieją ograniczanie wyjaśnień naukowych do naturalnych, bezosobowych i nieinteligentnych przyczyn. Przeciwstawiają zatem wymienionym przyczynom przyczyny inteligentne i celowe, a nie nadnaturalne:

Naturalistyczna teoria ewolucji [...] stwierdza, że stworzenie zostało dokonane przez bezosobowe i nieinteligentne siły.

JoHnson, Reason in Balance..., s. 108.

${ }^{87}$ Charles Tнахтол, „Nowy argument z projektu”, przeł. Izabela Janus, Filozoficzne Aspekty Genezy 2011, t. 8, s. 156 [155-177], http://www.nauka-a-religia.uz.zgora.pl/images/FAG/2011.t.8/ art.02.pdf (24.01.2018). Por. też MEYer, „Demarkacja nauki i religii...”, s. 181; Thomas WOODWARD, „Istota sporu darwinizmu z teorią inteligentnego projektu: przyrodnicza symfonia makroewolucji”, przeł. Dariusz Sagan, Filozoficzne Aspekty Genezy 2007/2008, t. 6/7, s. 15 [7-20], http://www.nauka-a-religia.uz.zgora.pl/images/FAG/2007-2008.t.4-5/art.01.pdf (27.01.2018); Dariusz S SAGAN, „Spór o możliwość wykrywania projektu w naukach przyrodniczych”, Scientia et Fides 2015, t. 3, nr 1, s. 94 [87-113], www.nauka-a-religia.uz.zgora.pl/images/Przedruki/Sagan Spor.o.mozliwosc.wykrywania.projektu.pdf (09.02.2018); Dariusz SAGAN, „Wspólnota pochodze- 


\section{Zgodnie z artyficjalistycznym EUO}

niektóre własności Wszechświata i organizmów żywych lepiej są wyjaśniane przez jakąś inteligentną przyczynę niż przez nieukierunkowany proces, taki jak dobór naturalny $[\ldots],{ }^{88}$

gdyż

bezosobowe i nieinteligentne przyczyny nie wystarczają, by wyjaśnić zarówno powstanie samego życia, jak i późniejsze wyewoluowanie rozmaitych jego form. ${ }^{89}$

Ten EUO przedstawić można jako nakaz dopuszczania w badaniach naukowych obok przyczyn naturalnych również przyczyn sztucznych, inteligentnych.

Nakaz ten podpada jedynie pod pewną wersję zasady inkluzji: ${ }^{90}$ dopuszcza się inne niż naturalistyczne wyjaśnienia (artyficjalistyczne) i jednocześnie po-

nia jako argument w sporze darwinizm-teoria inteligentnego projektu", Diametros 2013, nr 37, s. 128 [127-145], www.nauka-a-religia.uz.zgora.pl/images/Przedruki/Sagan_Wspolnota.pochodze nia.pdf (17.02.2018).

${ }^{88}$ Strona internetowa Discovery Institute - głównego ośrodka propagującego teorię inteligentnego projektu: http://www.discovery.org/id/faqs (20.03.2017) [wyróżnienie dodane]. Por. też np. „Top Questions and Answers on Intelligent Design”, 8 September 2005, http://www.discovery .org/a/2348 (20.01.2018); William A. Dembski, „The Intelligent Design Movement”, http://www. arn.org/docs/dembski/wd_idmovement.htm (10.02.2018); wypowiedź Michaela Behe'ego w: Mark RyLand, „«Teoria inteligentnego projektu» podważa teorię ewolucji. Już sama złożoność stworzenia świadczy o działaniu siły wyższej. Darwinizm? Nie ma szans. Wywiad z Michaelem J. Behe'em dla Our Sunday Visitor", przeł. Dariusz Sagan, Na Początku ... 2004, nr 11-12A (187188), s. 415 [414-420], www.nauka-a-religia.uz.zgora.pl/images/Przedruki/Ryland_Teoria.ID.pod waza.teorie.ewolucji.pdf (22.01.2018); JoDKowski, „Konflikt nauka-religia...”, s. 167, 169; JoDKowski, „Epistemiczny układ odniesienia...”, s. 100-101; Kazimierz JoDKowski, „Wstęp do teorii inteligentnego projektu", Fronda 2012, nr 63, s. 22-23 [16-32], www.nauka-a-religia.uz.zgora.pl/ images/Przedruki/Jodkowski_Wstep.do.teorii.ID.pdf (21.01.2018); Dariusz SAGAN, „Molekularny «zegar Paleya» a darwinowska ewolucja”, Ruch Filozoficzny 2005, t. LXII, nr 2, s. 289-290 [289304], http://tiny.pl/xh8tk (21.01.2018).

${ }^{89}$ JoDKowsKI, „Konflikt nauka-religia...”, s. 174. Por. też wypowiedź Dariusza Sagana w: Bylica, Jodkowski, Kilian i Sagan, „Dyskusja nad artykułem Adama Groblera...”, s. 51; SAgan, „Teoria inteligentnego projektu a ewolucjonizm...”, s. 81-82; Bogusław WóJcik, „Czy teoria inteligentnego projektu i neodarwinizm mogą być komplementarne?", Zagadnienia Filozoficzne w Nauce 2007, nr XLI, s. 30 [28-45], http://tiny.pl/gkg4g (21.01.2018).

${ }^{90}$ O'Connor (por. O’Connor, „Nauka przed sądem...”, s. 97) zasadę tę w sformułowanej przez siebie postaci przypisuje również zwolennikom teorii inteligentnego projektu. 
wstrzymuje się od prób rozstrzygania natury projektanta. ${ }^{91}$ Nakaz dopuszczania w badaniach naukowych przyczyn inteligentnych można nazwać ograniczoną zasadą inkluzji, gdyż ID, w swoim obrębie, nie wypowiada się w sprawie dopuszczalności wyjaśnień nadnaturalistycznych: ${ }^{92}$

wyjaśnienia nadnaturalistyczne, odwołujące się do cudów, nie są naukowe [...] [a] wyjaśnienia, które odwołują się do inteligentnej przyczyny, nie wymagają żadnych cudów, ale nie można ich zredukować do mechanizmów materialistycznych. ${ }^{93}$

${ }^{91}$ Por. np. Michael J. Bene, „Współczesna hipoteza inteligentnego projektu. Łamanie reguł”, przeł. Dariusz Sagan, Na Początku ... 2004, R. 12, nr 7-8 (183-184), s. 244 [244-266], http://tiny. pl/xhn87 (28.01.2018); JodKowski, „Rozpoznawanie genezy...”, s. 188; Kazimierz JodKowski, „Czy teoria inteligentnego projektu posiada konsekwencje, dotyczące istnienia nadnaturalnego projektanta? Polemika z Elliottem Soberem", Filozoficzne Aspekty Genezy 2007/2008, t. 6/7, s. 42-44 [41-49], http://www.nauka-a-religia.uz.zgora.pl/images/FAG/2007-2008.t.4-5/art.07.pdf (27.01.2018); Dariusz SAGAN, „Teleologiczne wyjaśnienie nieredukowalnej złożoności układów biochemicznych", Roczniki Filozoficzne 2006, t. LIV, nr 1, s. 148-151 [139-160], https://www. kul.pl/files/581/Roczniki_Filozoficzne/Roczniki_Filozoficzne_54_1_2006/Sagan_139.pdf (04.02. 2018).

${ }^{92}$ Teoretycy inteligentnego projektu nie rozwiązują konfliktu nauka-religia przez promowanie nadnaturalizmu, jak kreacjoniści.

Jodkowski, „Konflikt nauka-religia...”, s. 173. Por. też David SNoKe, „Biologia systemowa jako paradygmat badawczy teorii inteligentnego projektu”, przeł. Dariusz Sagan, Filozoficzne Aspekty Genezy 2015, t. 12, s. 256-257 [255-285], http://www.nauka-a-religia.uz.zgora.pl/ima ges/FAG/2015.t.12/art.03.pdf(15.01.2018).

Członkowie Ruchu ID [...] w ogóle nie odwołują się do Biblii ani do jakiejkolwiek doktryny religijnej.

Dariusz SAGAN, „Retoryczna historia Ruchu Inteligentnego Projektu”, Diametros 2005, nr 4, s. 78 [76-85], www.nauka-a-religia.uz.zgora.pl/images/Przedruki/Sagan_Retoryczna.historia.Ru chu.ID.pdf (21.01.2018). Por. też Dariusz SAGAN, Spór o nieredukowalną zlożoność układów biochemicznych, Biblioteka Filozoficznych Aspektów Genezy, t. 5, Wydawnictwo MEGAS, Warszawa 2008, s. 15-16, www.nauka-a-religia.uz.zgora.pl/images/Przedruki/Sagan_Spor.o.niereduko walna.zlozonosc.pdf (23.01.2018).

Innym zagadnieniem jest sprawa prywatnych przekonań i dążeń większości teoretyków projektu. W „Strategii klina”, dokumencie przedstawiającym strategię Ruchu Inteligentnego Projektu, przeczytać można, że jednym z celów tego ruchu jest

zastąpienie wyjaśnień materialistycznych podejściem teistycznym, zgodnie z którym przyroda i ludzie stworzeni zostali przez Boga. 
Przedmiotem badań teorii inteligentnego projektu ${ }^{94}$ nie jest projektant, lecz projekt. ${ }^{95}$ Ten ostatni ma być wykrywalny empirycznie. Odróżnia się bowiem projekt wykrywalny empirycznie od projektu empirycznie niewykrywalnego. Ten pierwszy nazywany jest ,projektem w sensie mocnym” (,projektem w sensie empirycznym”), zaś ten drugi „projektem w sensie słabym” (,projektem w sensie metafizycznym"). ${ }^{96}$ Tylko ten pierwszy jest przedmiotem badań teorii ID. ${ }^{97}$

Discovery Institute, „The Wedge Strategy”, http://www.antievolution.org/features/wedge. html (27.01.2018). Por. też JodKowsKI, „Antynaturalizm teorii inteligentnego projektu...”, s. 6667; Elliott Sober, „Teoria inteligentnego projektu a nadnaturalizm - o tezie, że projektantem może być Bóg lub istoty pozaziemskie", przeł. Sławomir Piechaczek, Filozoficzne Aspekty Gene$z y$ 2007/2008, t. 6/7, s. 24 [21-39], http://www.nauka-a-religia.uz.zgora.pl/images/FAG/20072008.t.4-5/art.06.pdf (27.01.2018); John RENNIE, „15 odpowiedzi na nonsensowne tezy kreacjonistów”, przeł. Karol Sabath, Świat Nauki 2002, nr 9, s. 66 [66-72], http://creationism.org.pl/grou ps/ptkrmember/spor/pl/Rennie,\%2015\%20odpowiedzi.pdf/view (13.02.2018); Robert T. PenNock, „Creationism and Intelligent Design”, Annual Review of Genomics and Human Genetics 2003, vol. 4, s. 148-150 [143-163], http://bio.classes.ucsc.edu/bio175/Other/Pennock 2003.pdf (03.01. 2018); Matthew J. Brauer, Barbara Forrest, and Steven G. Gey, „Is It Science Yet?: Intelligent Design Creationism and the Constitution", Washington University Law Review 2005, vol. 83, no. 1, s. 35-38 [1-150], http://openscholarship.wustl.edu/law_lawreview/vol83/iss1/1/ (03.01.2018).

Wierzę w życzliwego Boga i uznaję, że filozofia i teologia są zdolne rozszerzyć ten argument. Lecz w biologii naukowy argument na rzecz projektu nie sięga tak daleko.

Behe, „Współczesna hipoteza...”, s. 244. Por. też Chaberek, „Świat jest zbyt złożony, by powstał przypadkowo...”, s. 34; JoDKowsкI, „Czy teoria inteligentnego projektu posiada konsekwencje...”, s. 45-46; Dariusz SAGAN, „Nieredukowalna złożoność jako świadectwo inteligentnego projektu”, Fronda 2012, nr 63, s. 59 [49-65], http://tiny.pl/ gkfxq (21.01.2018); Dariusz SAGAN, „Teoria inteligentnego projektu a kreacjonizm", Kwartalnik Filozoficzny 2015, t. XLIII, z. 2, s. 144145 [131-150], www.nauka-a-religia.uz.zgora.pl/images/Przedruki/Sagan Teoria.ID.a.kreacjoniz m.pdf (09.02.2018); SAGAN, „Spór o możliwość wykrywania projektu...”, s. 92; SAGAN, „Teoria inteligentnego projektu - argumenty za i przeciw...”, s. 340-341; NAGEL, „Public Education and Intelligent Design...”, s. 188; Provine, „Projekt? Tak! Ale czy inteligentny...”, s. 217; H. Allen ORR, „Ponownie darwinizm kontra inteligentny projekt”, przeł. Dariusz Sagan, Filozoficzne Aspekty Genezy 2004, t. 1, s. 33-48, www.nauka-a-religia.uz.zgora.pl/images/FAG/2004.t.1/art. 05.pdf (02.02.2018); Mark Perakh, „Nieredukowalna sprzeczność”, przeł. Dariusz Sagan, Filozoficzne Aspekty Genezy 2004, t. 1, s. 71 [71-113], www.nauka-a-religia.uz.zgora.pl/images/FAG/ 2004.t.1/art.04.pdf(03.02.2018).

${ }^{93}$ William A. Dembski and Jonathan Wells, The Design of Life: Discovering Signs of Intelligence in Biological Systems, Foundation for Thought and Ethics, Dallas 2008, s. 13 (cyt. za: Casey Luskin, „Teoria inteligentnego projektu nie wypowiada religijnych twierdzeń o sferze nadnaturalnej”, przeł. Izabela Janus, Filozoficzne Aspekty Genezy 2009/2010, t. 6/7, s. 112 [93- 
Twarde jądro artyficjalizmu sformułować można tak: obok przypadku i konieczności w bezpośredni sposób w przyrodzie działają również inteligentne przyczyny. ${ }^{98}$

Obecność tego metafizycznego komponentu teorii inteligentnego projektu nie zawsze jest rozpoznawana lub też bywa ignorowana. Świadczy o tym następująca wypowiedź:

116], http://tiny.pl/xhnlg [25.01.2018]).

${ }^{94}$ Nazwą ,inteligentny projekt” w rozważanym tu kontekście posłużył się jako pierwszy nie miecko-angielski filozof Ferdinand Canning Scott Schiller w eseju „Darwinism and Design” z 1897 roku (por. Jonathan WIтT, ,Zarys historii powstania naukowej teorii inteligentnego projektu”, przeł. Dariusz Sagan, Na Poczatku ... 2005, nr 9-10 (198-199), s. 353 [352-362], www.naukaa-religia.uz.zgora.pl/images/Przedruki/Witt_Historia.powstania.ID.pdf [22.01.2018]). Napisał tam tak:

trudno będzie odrzucić przypuszczenie, że proces ewolucji może być kierowany przez jakiś inteligentny projekt.

Ferdinand C.S. Schiller, „Darwinism and Design”, w: Ferdinand C.S. Schiller, Humanism: Philosophical Essays, The Macmillan Company, London and New York 1903, s. 141 [128-156], https://archive.org/stream/cu31924029012171\#page/n169/mode/2up/search/design (22.01.2018).

${ }^{95}$ Por. Discovery Institute, „Falsyfikowalność teorii inteligentnego projektu”, przeł. Dariusz Sagan, Na Poczatku... 2005, nr 11-12A (200-201), s. 455 [455-457], www.nauka-a-religia.uz.zgo ra.pl/images/Przedruki/Discovery.Institute_Falsyfikowalnosc.teorii.ID.pdf (23.01.2018); JoDKowSKI, „Wstęp do teorii inteligentnego projektu...”, s. 24. Por. też Dariusz SAGAN, „Teoria inteligentnego projektu a kreacjonizm...", s. 133.

${ }^{96}$ Naturalista metodologiczny, który jest zarazem teistą,

postrzega ewolucję jako Boską metodę stworzenia życia, lecz z góry odrzuca możliwość, by Bóg mógł zostawić jakieś empiryczne ślady, posługując się tą metodą stworzenia.

DemBSKI, „Odmiany naturalizmu...”, s. 47.

${ }^{97} \mathrm{O}$ tym drugim mówią teistyczni ewolucjoniści na przykład wtedy, gdy postulują istnienie subtelnego zestrojenia człowieka i wszechświata (por. Dariusz SAGAN, „Odpowiedź na uwagi polemiczne ks. dra Marka Słomki do mojego artykułu o filtrze eksplanacyjnym”, Roczniki Filozoficzne 2009, t. LVII, nr 1, s. 345-346 [345-349], www.nauka-a-religia.uz.zgora.pl/images/Przedru ki/Sagan_Odpowiedz.na.uwagi.polemiczne.pdf (21.01.2018); Dariusz SAGAN, „Filtr eksplanacyjny: wykrywanie inteligentnego projektu na gruncie nauk przyrodniczych”, Roczniki Filozoficzne 2009, t. LVII, nr 1, s. 170 przyp. 35 [157-193], www.nauka-a-religia.uz.zgora.pl/images/Przedru ki/Sagan_Filtr.eksplanacyjny.pdf (21.01.2018); Dariusz SAGAN, „Michaela Behe'ego koncepcja 
Teoria inteligentnego projektu, będąc teorią naukową, opiera się wyłącznie na wiedzy wypływającej z danych doświadczalnych oraz nie stawia i nie rozwiązuje zagadnień religijnych, dotyczących tożsamości projektanta czy jego metafizycznej natury. Wynika $\mathrm{z}$ tego, że teoria ta nie jest odmianą kreacjonizmu i nie wychodzi poza granice nauki. [...], ,Wskazuje ona jedynie, że życie ma inteligentne źródło". ${ }^{99}$

Spór o naukowy status teorii tej nie dotyczy jednak tego, jakimi metodami się ona posługuje, tylko tego, jakiego rodzaju wyjaśnienia dopuszcza: ${ }^{100}$

propozycja ponownego wprowadzenia przyczyn inteligentnych do eksplanacyjnego arsenału nauki [...] jest radykalnym odstępstwem od konwencjonalnej nauki. ${ }^{101}$

Przedostatni cytat raz jeszcze potwierdza przekonanie, w myśl którego teza o nieredukowalnej obecności filozofii w nauce nie jest jeszcze w pełni uznawana lub rozpoznawana.

nieredukowalnej złożoności”, Na Początku... 2003, nr 11-12 (174-175), s. 403 [402-417], www. nauka-a-religia.uz.zgora.pl/images/Przedruki/Sagan_Michaela.Beheego.koncepcja.IC.pdf (02.02. 2018).

${ }^{98}$ Por. Dariusz SAGAN, „Wyjaśnianie za pomocą praw przyrody jako warunek naukowości w sporze o ewolucje i inteligentny projekt", Studia Philosophiae Christianae 2013, t. 49, nr 1, s. 94 [93-116], www.nauka-a-religia.uz.zgora.pl/images/Przedruki/Sagan_Wyjasnianie.za.pomoca .praw.przyrody.pdf (10.02.2018); SAGAN, ,Teoria inteligentnego projektu - argumenty za i przeciw...", s. 335.

${ }^{99}$ LuskIn, „Teoria inteligentnego projektu nie wypowiada religijnych twierdzeń...”, s. 94, 96. Ostatnie zdanie, którym wspiera Luskin swoje przekonanie, przytacza on za: DAvIS and KeNYON, Of Pandas and People..., s. 161.

${ }^{100}$ Por. np. Michael J. BeHE, „Nieredukowalna złożoność: problem dla ewolucjonizmu darwinowskiego", przeł. Dariusz Sagan, Filozoficzne Aspekty Genezy 2005/2006, t. 2/3, s. 74 [67-96], http://www.nauka-a-religia.uz.zgora.pl/images/FAG/2005-2006.t.2-3/art.01.pdf (30.01.2018); BYLICA, KILIAN i SAGAN, „Wstęp...”, s. 18; SAGAN, „Kazimierz Jodkowski o teorii inteligentnego projektu...”, s. 217; SAGAN, „Nieredukowalna złożoność jako świadectwo inteligentnego projektu...”, s. 52-53; SAGAN, „Teoria inteligentnego projektu a ewolucjonizm...”, s. 81-82; Dariusz SAGAN, „Zdolność przewidywania jako warunek naukowości...”, s. 270; JоDKOwSKI, „Wstęp do teorii inteligentnego projektu...", s. 30-31.

${ }^{101}$ WoODWARD, „Istota sporu darwinizmu z teorią inteligentnego projektu...”, s. 16. Por. też Taner EdIs, „Dlaczego «teoria inteligentnego projektu» jest bardziej interesująca niż tradycyjny kreacjonizm”, przeł. Dariusz Sagan, Filozoficzne Aspekty Genezy 2007/2008, t. 6/7, s. 83 [81-93], http://tiny.pl/xh8mc (29.01.2018); ORR, „Ponownie darwinizm kontra inteligentny projekt...”, s. 34; SAGAN, „Teoria inteligentnego projektu a ewolucjonizm...”, s. 85; Joshua A. SMART, „O zastosowaniu pojęcia nieredukowalnej złożoności”, Na Początku... 2004, nr 11-12A (187-188), s. 422 [421-447], http://tiny.pl/xh4f4 (12.02.2018). 


\section{Podsumowanie}

Nazwa „epistemiczny układ odniesienia” została wprowadzona przez Kazimierza Jodkowskiego w 2004 roku i jest efektem jego uprzednich analiz sporu ewolucjonizmu z kreacjonizmem. Analizy te uwypukliły fakt nieredukowalnej obecności metafizycznych założeń w nauce i pokazały, że koszty epistemiczne akceptacji idei EUO prowadzą do odrzucenia ideału bezzałożeniowości. W jego miejsce przyjmowana jest teza o założeniowości, zgodnie z którą nauka nie może istnieć bez filozoficznych założeń.

EUO to, przyjmowane na mocy decyzji uczonych, niewielkie, dwu- lub trzyelementowe zbiory najogólniejszych, historycznie zmiennych założeń, które określają konieczne warunki uprawiania nauki.

Współcześnie o palmę elementarnego wymogu naukowości konkurują naturalizm w swoich dwóch odmianach (antynadnaturalistycznej i antyartyficjalistycznej) z nadnaturalizmem $i$ artyficjalizmem.

EUO naturalizmu antynadnaturalistycznego to nakaz przyjmowania jedynie naturalistycznych wyjaśnień dla faktów i procesów, któremu towarzyszy zakaz przyjmowania wyjaśnień antynaturalistycznych, pojmowanych jako zakaz powoływania się na przyczyny nadnaturalne.

Twarde jądro tej wersji naturalizmu mówi, że Boga albo nie ma, albo nie działa w przyrodzie w bezpośredni sposób.

EUO naturalizmu antyartyficjalistycznego to nakaz przyjmowania jedynie naturalistycznych wyjaśnień dla faktów i procesów, któremu towarzyszy zakaz przyjmowania wyjaśnień antynaturalistycznych, pojmowanych jako zakaz powoływania się na przyczyny sztuczne (inteligentne, celowe).

Twarde jądro tej wersji naturalizmu mówi, że na przebieg zdarzeń we Wszechświecie nie działa żaden inteligentny czynnik.

Pierwsze, nowożytne ślady ograniczania nauki do wyjaśnień naturalistycznych odnaleźć można u Francisa Bacona, który zalecał, aby wyjaśnienia w naukach przyrodniczych zawężać do przyczyn materialnych i sprawczych.

Trzy podstawowe źródła naturalizmu metodologicznego to: (1) mechanicystyczna filozofia osiemnastego stulecia, która dostarczyła mu ontologii (istnieje 
jedynie materia i ruch); (2) XIX-wieczna filozofia pozytywistyczna, która dostarczyła mu epistemologii (sensowne są tylko te zdania, które mówią o materii i ruchu) oraz (3) teologia, która wyłączyła refleksję o Bogu z racjonalnego dyskursu.

Główną ideę naturalizmu metodologicznego - wyrażaną przekonaniem, że zjawiska tego świata wyjaśniać należy wyłącznie za pomocą verae causae, przyczyn odwołujących się jedynie do zjawisk naturalnych — przypisuje się Karolowi Darwinowi. Angielskiemu przyrodnikowi przypisuje się też zdefiniowanie, za pomocą postulatu naturalizmu metodologicznego, współczesnego rozumienia naukowości. I to dopiero za sprawą autora $\mathbf{O}$ powstawaniu gatunków naturalizm ten zaczął $\mathrm{w}$ pełni funkcjonować jako elementarny wymóg uprawiania nauki.

Przeważnie twierdzi się, że terminem „naturalizm metodologiczny” po raz pierwszy posłużył się amerykański filozof Paul de Vries w 1983 roku. Jednak wcześniej, bo w 1936 roku, użył go inny amerykański filozof i metodystyczny teolog Edgar Sheffield Brightman.

EUO nadnaturalizmu (czyli kojarzonego z kreacjonizmem nadnaturalistycznego interwencjonizmu) to nakaz dopuszczania $\mathrm{w}$ wyjaśnianiu zjawisk przyrodniczych obok przyczyn naturalnych również wyjaśnień odwołujących się do przyczyn nadnaturalnych - interwencji bytu nadprzyrodzonego, czyli Boga.

Twarde jądro nadnaturalizmu składa się z trzech tez: Bóg działa w przyrodzie w bezpośredni sposób, zaś życie jest Jego unikalnym dziełem okresu stworzenia. Stworzenie dokonało się na mocy unikalnych procesów dziś już nie występujących.

EUO, kojarzonego z teorią inteligentnego projektu, artyficjalizmu to nakaz dopuszczania $\mathrm{w}$ badaniach naukowych obok przyczyn naturalnych również przyczyn sztucznych, inteligentnych.

Twarde jądro artyficjalizmu sprowadza się do następującej tezy: obok przypadku i konieczności w bezpośredni sposób w przyrodzie działają również inteligentne przyczyny.

Założenia (nakazy i zakazy), na których bazują EUO, nie są naukowo uzasadnialne bez popadnięcia $\mathrm{w}$ błędne koło, gdyż wszelkie, uznawane za naukowe, badania już owe założenia przyjmują. Wydawać by się mogło, że EUO moż- 
na próbować uzasadniać z poziomu metanaukowego. Jeśli spośród alternatywnych hipotez naukowych wybiera się taką, która proponuje najlepsze wyjaśnienie zjawisk w danej dziedzinie, to, kierując się tą samą zasadą, spośród alternatywnych EUO należy wybrać taki, który lepiej od innych kieruje pracami badawczymi w danej dziedzinie. Uzasadnianie takie obciążone jest jednak istotnymi ograniczeniami. Przyjęcie takiego metanaukowego uzasadnienia uzależnione jest od odrzucenia tezy o niewspółmierności i tezy o stratach.

Koncepcja epistemicznych układów odniesienia zasługuje na uwagę $\mathrm{z}$ dwóch powodów. Po pierwsze, dlatego, że jest ważnym głosem w sporze o racjonalność nauki. Pokazuje, że spór ten toczy się na znacznie bardziej podstawowym poziomie niż sugerowały to wszystkie, wcześniejsze ujęcia tego problemu. Jest też koncepcją trafnie opisującą mechanizmy uznawania poglądów i teorii za naukowe lub nienaukowe. Po drugie, dlatego, że odnosi się ona również do istotnego dla kultury Zachodu konfliktu między nauką a religią i odsłania jego podłoże. Omówienie tych zagadnień daleko wykracza poza ramy jednego artykułu. Będą one przedmiotem moich kolejnych publikacji poświęconych problematyce EUO.

Krzysztof J. Kilian

\section{Bibliografia}

Aikin Scott F., Harbour Michael, and Talisse Robert B., „Nagel on Public Education and Intelligent Design”, Journal of Philosophical Research 2010, vol. 35, s. 209-219, http://ti ny.pl/gkfh3 (01.01.2018).

Ayala Francisco J., „Darwin's Revolution”, w: CAmpbell and Schoff (eds.), Creative Evolution..., s. 1-18.

Bacon Francis, The Advancement of Learning, P.F. Collier and Son, New York 1901, http://oll.libertyfund.org/titles/bacon-the-advancement-of-learning (20.01.2018).

BAŁĘKOWSKI Krzysztof i MACIĄG Kamil (red.), Wybrane zagadnienia z filozofii języka i religii, Fundacja na rzecz promocji nauki i rozwoju TYGIEL, Lublin 2015.

BARTLETT Jonathan, „Filozoficzne wady naturalizmu metodologicznego i perspektywy na przyszłość”, przeł. Dariusz Sagan, Filozoficzne Aspekty Genezy 2017, t. 14, s. 53-87, http:// www.nauka-a-religia.uz.zgora.pl/images/FAG/2017.t.14/art.02.pdf (19.02.2018). 
BartLEtt Jonathan, „Philosophical Shortcomings of Methodological Naturalism and the Path Forward", w: Bartlett and Holloway (eds.), Naturalism and Its Alternatives..., s. 13-37, http://tiny.pl/gkdb2 (18.01.2018).

Bartlett Jonathan and Holloway Eric, „Introduction”, w: Bartlett and Holloway (eds.), Naturalism and Its Alternatives..., s. 1-9.

Bartlett Jonathan and Holloway Eric (eds.), Naturalism and Its Alternatives in Scientific Methodologies: Proceedings of the 2016 Conference on Alternatives to Methodological Naturalism, Blyth Institute Press, Broken Arrow, Oklahoma 2017.

BartLetT Jonathan and Holloway Eric, „Nienaturalistyczne metodologie we współczesnej praktyce”, przeł. Dariusz Sagan, Filozoficzne Aspekty Genezy 2016, t. 13, s. 101-117, http://www.nauka-a-religia.uz.zgora.pl/images/FAG/2016.t.13/art.08.pdf (10.03.2018).

Bartlett Jonathan and Holloway Eric, „Other Non-Naturalistic Methodologies in Modern Practice”, w: Bartlett and Holloway (eds.), Naturalism and Its Alternatives..., s. 257268.

BeHE Michael J., „Nieredukowalna złożoność: problem dla ewolucjonizmu darwinowskiego", przeł. Dariusz Sagan, Filozoficzne Aspekty Genezy 2005/2006, t. 2/3, s. 67-96, http:// www.nauka-a-religia.uz.zgora.pl/images/FAG/2005-2006.t.2-3/art.01.pdf (30.01.2018).

BeHE Michael J., „Współczesna hipoteza inteligentnego projektu. Łamanie reguł”, przeł. Dariusz Sagan, Na Początku... 2004, R. 12, nr 7-8 (183-184), s. 244-266, http://tiny.pl/xhn 87 (28.01.2018).

Berman Marshall, „Intelligent Design Creationism: A Threat to Society - Not Just Biology”, The American Biology Teacher 2003, vol. 65, no. 9, s. 646-648.

Bishop Robert C., „God and Methodological Naturalism in the Scientific Revolution and Beyond", Perspectives on Science and Christian Faith 2013, vol. 65, no. 1, s. 10-23, http:// tiny.pl/gkfxt (24.01.2018).

Borczyk Bartosz, Chmielewski Adam, Elżanowski Andrzej, Jodkowski Kazimierz, LeszCZyŃSKi Damian, Lukierski Jerzy, Nysler Łukasz i Pawłowski Bogusław, „Dyskusja”, w: LESZCZYŃSKi (red.), Ewolucja, filozofia, religia..., s. 155-172, www.nauka-a-religia.uz.zgo ra.pl/images/Przedruki/Jodkowski_Dyskusja.o.Darwinie.pdf (06.02.2018).

Brauer Matthew J., Forrest Barbara, and Gey Steven G., „Is It Science Yet?: Intelligent Design Creationism and the Constitution", Washington University Law Review 2005, vol. 83, no. 1, s. 1-150 http://openscholarship.wustl.edu/law_lawreview/vol83/iss1/1/ (03.01. 2018).

Brightman Edgar Sheffield, „An Empirical Approach to God”, The Philosophical Review 1937, vol. XLVI, no. 2, s. 147-169, http://www.jstor.org/stable/1483003?seq=1\#page_ scan_tab_contents (28.01.2018). 
Browne E. Janet, Charles Darwin: The Power of Place, Princeton University Press, Princeton 2003

BugAJaK Grzegorz, „Adekwatność tezy o rozdzielności płaszczyzn poznawczych. Głos w imieniu mieszkańców «opancerzonego bunkra»", w: BylicA, Kilian, Piotrowski i Sagan (red.), Filozofia — nauka — religia..., s. 173-190, http://tiny.pl/gkfx7 (17.05.2017).

ByLICA Piotr, „Darwin o celowości w przyrodzie”, Kwartalnik Historii Nauki i Techniki 2008, R. 53, nr 3-4, s. 269 259-273, http://www.nauka-a-religia.uz.zgora.pl/images/Przedru ki/Bylica_Darwin.o.celowosci.w.przyrodzie.pdf (20.01.2018).

ByLICA Piotr, „Główne założenia i problemy teizmu naturalistycznego w sprawie relacji sfery nadprzyrodzonej i świata przyrodniczego", w: Dyк (red.), Sozologia systemowa..., s. 55-95, www.nauka-a-religia.uz.zgora.pl/images/Przedruki/Bylica_Glowne.zalozenia.teiz mu.naturalistycznego.pdf (31.01.2018).

Bylica Piotr, „Kazimierza Jodkowskiego koncepcja epistemicznych układów odniesienia a teizm naturalistyczny Johna Polkinghorne'a", w: Bylica, Kilian, Piotrowski i Sagan (red.), Filozofia — nauka - religia..., s. 191-211, www.nauka-a-religia.uz.zgora.pl/ima ges/Przedruki/Bylica_Kazimierza.Jodkowskiego.koncepcja.epistemicznych.ukladow.odnies ienia.pdf (18.01.2018).

ByLICA Piotr, „Konflikt między teizmem i nauką bazującą na naturalizmie - w ujęciu Phillipa E. Johnsona", Zagadnienia Naukoznawstwa 2003, nr 3-4 (157-158), s. 227-238, www.nauka-a-religia.uz.zgora.pl/images/Przedruki/Bylica_Konflikt.miedzy.teizmem.i.nauk a.pdf (06.02.2018).

ByLICA Piotr, „Mark Harris as a Naturalistic Theist: The Perspective of the Model of Levels of Analysis", Filozoficzne Aspekty Genezy 2015, t. 12, s. 7-36, http://www.nauka-a-religia. uz.zgora.pl/images/FAG/2015.t.12/art.11.pdf (14.02.2018).

ByLICA Piotr, „Naturalizm metodologiczny jako warunek naukowości w kontekście relacji nauki i religii", Przeglad Filozoficzny - Nowa Seria 2004, R. 13, nr 3 (51), s. 163-175, http://tiny.pl/xh8g4 (04.02.2018).

ByLICA Piotr, „Nauka światopoglądowo neutralna?”, Fronda 2012, nr 63, s. 67-80, http://ti ny.pl/gkfxr (18.01.2018).

BYLICA Piotr, „Spór o naukowość teorii inteligentnego projektu”, w: JoDKowski (red.), Teoria inteligentnego projektu..., s. 51-78, www.nauka-a-religia.uz.zgora.pl/images/Przedru ki/Bylica_Spor.o.naukowosc.teorii.ID.pdf(14.02.2018).

ByLICA Piotr, „Zaburzenia dysocjacyjne czy opętanie przez Szatana. Historyczno-metodologiczna analiza stosunku psychiatrii do problemu opętań”, w: ZoN (red.), Pogranicza nauki..., s. 209-225, www.nauka-a-religia.uz.zgora.pl/images/Przedruki/Bylica_Zaburzenia. dysocjacyjne.pdf (04.02.2018).

BYLICA Piotr, Współczesny teizm naturalistyczny z punktu widzenia modelu poziomów analizy. Problem dzialania sfery nadnaturalnej w przyrodzie, Biblioteka Filozoficznych 
Aspektów Genezy, t. 7, Instytut Filozofii Uniwersytetu Zielonogórskiego, Zielona Góra 2016, http://tiny.pl/gkdv1 (16.01.2018).

Bylica Piotr, JodKowski Kazimierz, Kilian Krzysztof J. i SAGAn Dariusz, ,,Dyskusja nad artykułem Adama Groblera, «Słabości eksplanacyjne teorii inteligentnego projektu»”, Filozoficzne Aspekty Genezy 2013, t. 10, s. 17-63, www.nauka-a-religia.uz.zgora.pl/images/ FAG/2013.t.10/art.14.pdf (16.01.2018).

Bylica Piotr, Kilian Krzysztof J., Piotrowski Robert i Sagan Dariusz (red.), Filozofia nauka - religia. Księga jubileuszowa dedykowana Profesorowi Kazimierzowi Jodkowskiemu z okazji 40-lecia pracy naukowej, Oficyna Wydawnicza Uniwersytetu Zielonogórskiego, Zielona Góra 2015, http://www.nauka-a-religia.uz.zgora.pl/images/Przedruki/ Filozofia.nauka.religia.pdf (31.01.2018).

Bylica Piotr, Kilian Krzysztof J., Sagan Dariusz, „Wstęp”, w: Bylica, Kilian, Piotrowski i SAGAN (red.), Filozofia - nauka - religia..., s. 11-33.

Campbell John H. and Schoff J.W. (eds.), Creative Evolution!?, Jones and Bartlett, New York 1994.

CenIAN Adam, „Wiara w naukę — jej podstawy, założenia, mocne i słabe strony kultu”, wystąpienie na Konferencji Chrześcijańskiego Forum Pracowników Nauki: Nauka - Etyka - Wiara, Rydzyna 30.05-02.06.2013, s. 151-159, http://www.chfpn.pl/files/?id plik=508 (15.01.2018).

CHABEREK Michał OP, „Świat jest zbyt złożony, by powstał przypadkowo. Rozmowa z Michaelem Behe'em", Fronda 2012, nr 63, s. 34-41.

Chaberek Michał OP, „Św. Tomasz z Akwinu a ewolucjonizm. Polemika z tezami Piotra Lichacza OP i Williama E. Carrolla", Filozoficzne Aspekty Genezy 2012, t. 9, s. 33-52, http://www.nauka-a-religia.uz.zgora.pl/images/FAG/2012.t.9/art.01.pdf (18.01.2018).

Coyne Jerry A., „Nowa fala fanatyzmu w nauce”, przeł. Dariusz Sagan, Filozoficzne Aspekty Genezy 2004, t. 1, s. 49-53, http://www.nauka-a-religia.uz.zgora.pl/images/FAG/2004. t.1/art.01.pdf (02.02.2018).

Coyne Jerry A., „Science, Religion, and Society: The Problem of Evolution in America”, Evolution. International Journal of Organic Evolution 2012, vol. 66, no. 8, s. 2654-2663, http://onlinelibrary.wiley.com/doi/10.1111/evo.2012.66.issue-8/issuetoc (30.01.2018).

CUBERBILLeR Marta, „Metodologiczne korzyści z istnienia teorii kreacjonistycznych”, w: GazDA (red.), Idź Pod Prąd w sporze ewolucjonizm-kreacjonizm..., s. 45-48.

Cuberbiller Marta, „O metodach datowania radioaktywnego”, w: GAZDA (red.), Idź Pod Prąd w sporze ewolucjonizm-kreacjonizm..., s. 230-233.

DARWIN Karol, Autobiografia i wybór listów. Dziela wybrane, t. 8, przeł. Anna Iwanowska, Aniela Makarewicz, Anna Straszewicz i Zdzisława Wójcik, Państwowe Wydawnictwo Rolnicze i Leśne, Warszawa 1960. 
DARWIN Karol, O powstawaniu gatunków drogą doboru naturalnego czyli o utrzymaniu się doskonalszych ras w walce o byt. Dziela wybrane, t. 2, przeł. Szymon Dickstein i Józef Nusbaum, Państwowe Wydawnictwo Rolnicze i Leśne, Warszawa 1959.

DARWIN Karol, Zmienność zwierząt i roślin w stanie udomowienia. Dzieła wybrane, t. 3, przeł. Kazimierz Brończyk, Państwowe Wydawnictwo Rolnicze i Leśne, Warszawa 1959.

Davis Percival and Kenyon Dean H., Of Pandas and People: The Central Question of Biological Origins, Foundation for Thought and Ethics, Richardson, Texas 1993.

DAwKINS Richard, Ślepy zegarmistrz, czyli jak ewolucja dowodzi, że świat nie zostal zaplanowany, przeł. Antoni Hoffman, Biblioteka Myśli Współczesnej, Państwowy Instytut Wydawniczy, Warszawa 1994.

DE Duve Christian, „The Beginning of Life on Earth”, American Scientist 1995, vol. 83, s. 428-437, http://pratclif.com/memes/deduve-begin-life1.html (07.02.2018).

DE VRIES Paul, „Naturalizm w naukach przyrodniczych. Perspektywa chrześcijańska”, przeł. Radosław Plato, Filozoficzne Aspekty Genezy 2011, t. 8, s. 121-135, http://www.nauka-areligia.uz.zgora.pl/images/FAG/2011.t.8/art.08.pdf (12.02.2018).

Dembski William A., „Odmiany naturalizmu. Czy któraś forma naturalizmu jest zgodna z teorią inteligentnego projektu?", przeł. Dariusz Sagan, Na Początku ... 2005, R. 13, nr 12, s. 45-54, www.nauka-a-religia.uz.zgora.pl/images/Przedruki/Dembski_Odmiany.naturali zmu.pdf(22.01.2018).

Dembsкi William A., „Powrót projektu do nauk przyrodniczych”, przeł. Dariusz Sagan, $\mathrm{Na}$ Poczatku... 2004, nr 9-10 (185-186), s. 323-342, www.nauka-a-religia.uz.zgora.pl/images/ Przedruki/Dembski_Powrot.projektu.pdf (22.01.2018).

Dembski William A., „The Intelligent Design Movement”, http://www.arn.org/docs/dembski /wd_idmovement.htm (10.02.2018).

Dembski William A. and Ruse Michael (eds.), Debating Design: From Darwin to DNA, Cambridge University Press, Cambridge 2004.

Dembski William A. and Wells Jonathan, The Design of Life: Discovering Signs of Intelligence in Biological Systems, Foundation for Thought and Ethics, Dallas 2008.

Dębowski Józef i Starzyńska-Kościuszko Ewa (red.), Nauka. Racjonalność. Realizm. Między filozofią przyrody a filozofią nauki i socjologią wiedzy, Instytut Filozofii Uniwersytetu Warmińsko-Mazurskiego w Olsztynie, Olsztyn 2013.

Dilley Stephen, „The Evolution of Methodological Naturalism in the Origin of Species”, HOPOS: The Journal of the International Society for the History of Philosophy of Science 2013, vol. 3, no. 1, s. 20-58, http://www.jstor.org/stable/10.1086/667897? seq=1\#page_ scan_tab_contents (23.01.2018). 
Discovery Institute, „Falsyfikowalność teorii inteligentnego projektu”, przeł. Dariusz Sagan, Na Poczatku ... 2005, nr 11-12A (200-201), s. 455-457, www.nauka-a-religia.uz.zgora. pl/images/Przedruki/Discovery.Institute_Falsyfikowalnosc.teorii.ID.pdf (23.01.2018).

Discovery Institute, „The Wedge Strategy”, http://www.antievolution.org/features/wedge. html (27.01.2018).

Dүк Wiesław (red.), Sozologia systemowa. Biosfera. Człowiek i jego środowisko w aspekcie przyrodniczym, filozoficznym i teologicznym, Wydawnictwo Naukowe Uniwersytetu Szczecińskiego, Szczecin 2012.

EDIS Taner, „Dlaczego «teoria inteligentnego projektu» jest bardziej interesująca niż tradycyjny kreacjonizm", przeł. Dariusz Sagan, Filozoficzne Aspekty Genezy 2007/2008, t. 6/7, s. 81-93, http://tiny.pl/xh8mc (29.01.2018).

Feyerabend Paul K., „Changing Patterns of Reconstruction”, British Journal for the Philosophy of Science 1977, vol. 28, no. 4, s. 351-369.

Feyerabend Paul K., Przeciw metodzie, przeł. Stefan Wiertlewski, Wydawnictwo Siedmioróg, Wrocław 1996.

Feyerabend Paul K., Science in a Free Society, Verso, London 1983.

Førland Tor Egil, „Acts of God?: Miracles and Scientific Explanation”, History and Theory 2008, vol. 47, no. 4, s. 483-494, http://www.chss.uqam.ca/Portals/0/docs/his7007/Tor\% 20Egil-Dieu-Hisitoire.pdf (01.01.2018).

Futuyma Douglas J., „Cuda a molekuły”, przeł. Dariusz Sagan, Filozoficzne Aspekty Genezy 2004, t. 1, s. 65-69, www.nauka-a-religia.uz.zgora.pl/images/FAG/2004.t.1/art.03.pdf (03.02.2018).

GAzDa Małgorzata (red.), Idź Pod Prąd w sporze ewolucjonizm-kreacjonizm, Wydawnictwo POD PRĄD, Lublin 2017.

Giberson Karl W. i YerXa Donald A., O gatunkach powstawania. W poszukiwaniu opowieści o stworzeniu, przeł. Dariusz Sagan, Biblioteka Filozoficznych Aspektów Genezy, t. 3, Wydawnictwo MEGAS, Warszawa 2008.

Gish Duane, Evolution: The Fossils Say No, Creation-Life Publishers, San Diego 1978.

Godek Lidia, Musiaz Maciej i Woszczak Marek (red.), X Polski Zjazd Filozoficzny. Księga streszczeń, Wydawnictwo Naukowe Instytutu Filozofii UAM, Poznań 2015.

Gordon Bruce L., „W obronie uniformitaryzmu”, przeł. Agnieszka Biesiadecka, Dorota Brylla, Małgorzata Gazda, Grzegorz Malec, Radosław Plato, Maciej Powąska, Alicja Ratajczak i Dariusz Sagan, Filozoficzne Aspekty Genezy 2014, t. 11, s. 133-149, http://www.nau ka-a-religia.uz.zgora.pl/images/FAG/2014.t.11/art.05.pdf(17.02.2018).

Grassé Pierre P., Evolution of Living Organisms: Evidence for a New Theory of Transformation, Academic Press Inc., New York 1977. 
Gregory Brad S., „No Room for God?: History, Science, Metaphysics, and the Study of Religion", History and Theory 2008, vol. 47, no. 4, s. 495-519, www.chss.uqam.ca/Portals/ 0/docs/his7007/Brad\%20S.\%20Gregory.pdf (01.01.2018).

Grigg Russell, „Tajemnicza choroba Darwina”, przeł. Andrew Ostapowicz, Creation Ministries International, http://creation.com/darwins-mystery-illness-polish (17.01.2018).

Harold Franklin M., The Way of the Cell: Molecules, Organisms, and the Order of Life, Oxford University Press, Oxford 2001.

HedtKe Randal, Secrets of the Sixth Edition: Darwin Discredits His Own Theory, Master Books, Green Forest 2010.

Heller Michał, „Konieczność i przypadek w ewolucji Wszechświata”, Zagadnienia Filozoficzne $w$ Nauce 2009, t. XLIV, s. 3-12, http://zfn.edu.pl/index.php/zfn/article/download/ 208/198 (30.01.2018).

Heller Michał, „Nie za bardzo inteligentny projekt”, Copernicus Center 24 grudnia 2014, https://www.copernicuscenter.edu.pl/nie-za-bardzo-inteligentny-inteligentny-projekt-25312 (10.02.2018).

Heller Michał, Sens życia i sens Wszechświata. Studia z teologii współczesnej, Biblos, Tarnów 2002.

Herschel John F.W., Preliminary Discourse on the Study of Natural Philosophy, Longman, Brown, Green \& Longmans, London 1851, https://archive.org/details/preliminarydis co00hersiala (08.02.2018).

Hodge Charles, What Is Darwinism?, Scribner, Armstrong and Company, New York 1874, http://tiny.pl/gkfxw (17.02.2018).

Holloway Eric, „Problems With Non-Naturalistic Theories of Science”, w: BartLEtT and Holloway (eds.), Naturalism and Its Alternatives..., s. 163-176.

IsAaC Randy, „Assessing the RATE Project”, Perspectives on Science and Christian Faith 2007, vol. 59, no. 2, s. 143-146, http://www.asa3.org/ASA/education/origins/rate-ri.htm (03.02.2018).

Janeczer Stanisław, Starościc Anna, DĄBEK Dariusz i Herda Justyna (red.), Filozofia przyrody, Dydaktyka Filozofii, t. III, Wydawnictwo Katolickiego Uniwersytetu Lubelskiego, Lublin 2013.

JoDKоwsкi Kazimierz, „Antynaturalizm teorii inteligentnego projektu”, Roczniki Filozoficzne 2006, t. 54, nr 2, s. 63-76, www.nauka-a-religia.uz.zgora.pl/images/Przedruki/Jodkow ski_Antynaturalizm.teorii.ID.pdf (16.02.2018).

Jodкошsкi Kazimierz, „Curriculum Vitae”, http://tiny.pl/gkfxf (08.02.2018).

JodKowski Kazimierz (red.), Czy sprzeczność może być racjonalna?, Realizm. Racjonalność. Relatywizm, t. 4, Wydawnictwo UMCS, Lublin 1986. 
JoDKоwsкi Kazimierz, „Czy teoria inteligentnego projektu posiada konsekwencje, dotyczące istnienia nadnaturalnego projektanta? Polemika z Elliottem Soberem", Filozoficzne Aspekty Genezy 2007/2008, t. 6/7, s. 41-49, http://www.nauka-a-religia.uz.zgora.pl/images/ FAG/2007-2008.t.4-5/art.07.pdf(27.01.2018).

JoDKowski Kazimierz, „Darwinowska teoria ewolucji jako teoria filozoficzna”, w: KoNSTAŃCZAK i TUROWSKI (red.), Filozofia jako mądrość bycia..., s. 17-23, http://tiny.pl/q3m56 (31.01.2018).

Jodкоwsк Kazimierz, „Dlaczego kreacjonizm jest pseudonauką?”, w: Zon (red.), Pogranicza nauki..., s. 317-323, www.nauka-a-religia.uz.zgora.pl/images/Przedruki/Jodkowski_ Dlaczego.kreacjonizm.jest.pseudonauka.pdf (31.01.2018).

JodKowski Kazimierz, „Epistemiczne układy odniesienia i «warunek Jodkowskiego»”, w: LATAWIEC i BugAJAK (red.), Filozoficzne i naukowo-przyrodnicze elementy obrazu świata..., s. 108-123, www.nauka-a-religia.uz.zgora.pl/images/Inne.teksty/Jodkowski Epistemi czne.uklady.odniesienia.i.warunek.Jodkowskiego.pdf (16.02.2018).

JoDKowski Kazimierz, „Epistemiczny układ odniesienia teorii inteligentnego projektu”, $F i$ lozofia Nauki 2006, nr 1 (53), s. 95-105, www.nauka-a-religia.uz.zgora.pl/images/Inne.tek sty/Jodkowski_Epistemiczny.uklad.odniesienia.teorii.ID.pdf (18.01.2018).

JoDKowski Kazimierz, „Eskapizm teologii i filozofii katolickiej w sprawie «nauka a religia»", Na Poczatku ... 2005, nr 7-8 (196-197), s. 261-284, www.nauka-a-religia.uz.zgora.pl/ images/Przedruki/Jodkowski_Eskapizm.teologii.i.filozofii.katolickiej.pdf (18.01.2018).

Jodkowski Kazimierz, „Filozofia nauki Paula K. Feyerabenda. Stadium umiarkowane”, Studia Filozoficzne 1979, nr 11 (168), s. 59-75.

JoDKowski Kazimierz, „Filozoficzna natura sporu ewolucjonizm-kreacjonizm. Refleksje po lekturze tekstu Phillipa E. Johnsona", Na Początku... 2000, nr 7-8 (131-132), s. 211-217, https://creationism.org.pl/artykuly/KJodkowski4 (02.02.2018).

JoDKowski Kazimierz, „Interpretacje Kuhnowskiej tezy o niewspółmierności”, Roczniki Filozoficzne 1984, t. 32, z. 3, s. 173-198.

JodKowski Kazimierz, „Jaka geometria obowiązuje we Wszechświecie?”, w: PIETRZAK (red.), Albert Einstein i rewolucja relatywistyczna..., s. 71-89, http://tiny.pl/gkfx1 (16. 01.2018).

JoDKowsKi Kazimierz, „Klasyfikacja stanowisk kreacjonistycznych”, Filozoficzne Aspekty Genezy 2005/2006, t. 2/3, s. 241-269, www.nauka-a-religia.uz.zgora.pl/images/FAG/20052006.t.2-3/art.11.pdf (02.02.2018).

JoDKowsKI Kazimierz, „Konflikt nauka-religia a teoria inteligentnego projektu”, w: JODKOWSKI (red.), Teoria inteligentnego projektu..., s. 145-180, http://tiny.pl/qzq82 (20.01. 2018). 
JoDKOwski Kazimierz, „Kreacjoniści przed sądem. Aspekty filozoficzne «małpich procesów»", w: Michalczenia, Mizińska i Ossowska (red.), Poszukiwania filozoficzne. Tom I..., s. 175-198, www.nauka-a-religia.uz.zgora.pl/images/Przedruki/Jodkowski_Kreacjonis ci.przed.sadem.Aspekty.filozoficzne.malpich.procesow.pdf (19.01.2018).

JoDKOwSKI Kazimierz, „Kreacjonizm a naturalizm nauk przyrodniczych”, Annales Universitatis Mariae Curie-Skłodowska, Sectio I, Lublin-Polonia 1996/1997, vol. XXI i XXII, s. 11-26, http://tiny.pl/gkfx4 (02.02.2018).

JoDKowski Kazimierz, „Kreacjonizm młodej Ziemi a koncepcja Big Bangu. Poglądy Johna Hartnetta z konstruktywistycznej i eksternalistycznej perspektywy", Filozoficzne Aspekty Genezy 2015, t. 12, s. 37-79, http://www.nauka-a-religia.uz.zgora.pl/images/FAG/2015.t. 12/art.12.pdf (14.02.2018).

JoDKowski Kazimierz, „Metafizyczne opowieści nauki jako fundament pluralizmu naukowego", w: JoHNSON, Wielka metafizyczna opowieść nauki..., s. 74-85, http://tiny.pl/q3m $5 \mathrm{p}(18.01 .2018)$

JoDKOwsKi Kazimierz, Metodologiczne aspekty kontrowersji ewolucjonizm-kreacjonizm, Realizm. Racjonalność. Relatywizm, t. 35, Wydawnictwo UMCS, Lublin 1998.

Jodkоwsкi Kazimierz, „Nauka w oczach Feyerabenda”, w: Jodkowski (red.), Czy sprzeczność może być racjonalna..., s. 227-270.

Jodкоwsк Kazimierz, „Niedocenianie filozofii. Błąd Phillipa E. Johnsona”, Na Początku... 2002, nr 1-2 (151-152), s. 14-19, https://creationism.org.pl/artykuly/KJodkowski\#txt2 (15. 01.2018).

Jodkowski Kazimierz, „Nienaukowy fundament nauki”, w: PietrzaK (red.), Granice nauki..., s. 59-108, www.nauka-a-religia.uz.zgora.pl/images/Przedruki/Jodkowski_Nienauko wy.fundament.nauki.pdf (18.01.2018).

JodKowski Kazimierz, „Noma, cudy i filtr eksplanacyjny”, Roczniki Filozoficzne 2005, t. 53, nr 2, s. 83-103, http://publikacje.uz.zgora.pl:7777/skep/docs/F23001/Jodkowski,\%20 NOMA\%20cudy\%20i\%20filtr\%20eksplanacyjny.doc (13.02.2018).

JoDKowsk Kazimierz, „O dwu rodzajach niewspółmierności interteoretycznej w ujęciu Paula K. Feyerabenda", Studia Filozoficzne 1980, nr 7, s. 79-91.

JoDKоwsкi Kazimierz, „Problem wyboru spośród niewspółmiernych teorii (analiza stanowiska P.K. Feyerabenda z tzw. okresu umiarkowanego)", Studia Filozoficzne 1984, nr 1 (218), s. 109-120.

JoDKowski Kazimierz, „Przedmowa”, Filozoficzne Aspekty Genezy 2004, t. 1, s. 5-6, www. nauka-a-religia.uz.zgora.pl/images/FAG/2004.t.1/art.09.pdf(02.02.2018).

JodKowski Kazimierz, „Racjonalność Kopernika i Darwina. Polemika z drem Eugeniuszem Moczydłowskim”, Na Początku... 2003, nr 11-12A (174-175), s. 433-448, www.nauka-a-re 
ligia.uz.zgora.pl/images/Przedruki/Jodkowski_Racjonalnosc.Kopernika.i.Darwina.pdf (14. 02.2018).

JoDKOwsKi Kazimierz, „Rodzaje procesu ewolucyjnego i sens przypadku. Wyjaśnianie nieporozumień - ciąg dalszy”, Filozofia Nauki 2006, nr 1 (53), s. 169-174, http://tiny.pl/q3m $5 \mathrm{k}(14.02 .2018)$.

JoDKowski Kazimierz, „Rozpoznawanie genezy: istota sporu ewolucjonizm-kreacjonizm”, Roczniki Filozoficzne 2002, t. 50, z. 3, s. 187-198, www.nauka-a-religia.uz.zgora.pl/images/ Przedruki/Jodkowski_Rozpoznawanie.genezy.pdf (19.01.2018).

JODKOwski Kazimierz, „Ruch kreacjonistyczny jest elementem pluralizmu naukowego”, Przegląd Filozoficzny - Nowa Seria 2001, R. X, nr 1 (37), s. 241-253, http://tiny.pl/gdw95 (08.01.2018).

Jodkowski Kazimierz, „Spisek Darwina”, w: LeszczYŃSKi (red.), Ewolucja, filozofia, religia..., s. 265-277, www.nauka-a-religia.uz.zgora.pl/images/Przedruki/Jodkowski_Spisek. Darwina.pdf (31.01.2018).

JoDKowsKI Kazimierz (red.), Teoria inteligentnego projektu - nowe rozumienie naukowości?, Biblioteka Filozoficznych Aspektów Genezy, t. 2, Wydawnictwo MEGAS, Warszawa 2007, http://www.nauka-a-religia.uz.zgora.pl/images/Przedruki/Jodkowski_red._Teoria. ID.nowe.rozumienie.naukowosci.pdf (20.01.2018).

Jodkowski Kazimierz, Teza o niewspólmierności w ujęciu Thomasa S. Kuhna i Paula K. Feyerabenda, Realizm. Racjonalność. Relatywizm, t. 1, Wydawnictwo UMCS, Lublin 1984.

JoDKowski Kazimierz, „Twarde jądro ewolucjonizmu”, Roczniki Filozoficzne 2003, t. 51, z. 3, s. 77-117, www.nauka-a-religia.uz.zgora.pl/images/Przedruki/Jodkowski_Twarde.jadr o.ewolucjonizmu.pdf (18.01.2018).

JoDKOwski Kazimierz, „Uczony w ciemnym budynku. Na marginesie metafory Elżbiety Kałuszyńskiej”, w: DĘBowski i StarzyńSKa-Kościuszko (red.), Nauka. Racjonalność. Realizm..., s. 55-67, www.nauka-a-religia.uz.zgora.pl/images/Przedruki/Jodkowski_Uczony. w.ciemnym.budynku.pdf (16.02.2018).

JoDKowski Kazimierz, „W poszukiwaniu twardego jądra ewolucjonizmu”, Filozofia Nauki 2001, nr 2 (34), s. 7-18, http://tiny.pl/xh81h (31.01.2018).

JODKOWSKI Kazimierz, Wspólnoty uczonych, paradygmaty i rewolucje naukowe, Realizm. Racjonalność. Relatywizm, t. 22, Wydawnictwo UMCS, Lublin 1990.

JoDKOwski Kazimierz, „Wstęp do teorii inteligentnego projektu”, Fronda 2012, nr 63, s. 1632, http://tiny.pl/gkfbn (21.01.2018).

JoDKOwski Kazimierz, „Zasadnicza nierozstrzygalność sporu ewolucjonizm-kreacjonizm”, Przegląd Filozoficzny - Nowa Seria 2012, nr 3 (83), s. 201-222, http://tiny.pl/gkfxn (18. 05.2017). 
Johnson Phillip E., „Głośna herezja w świątyni Darwina”, przeł. Kazimierz Jodkowski, w: JoDкошsкi, Metodologiczne aspekty..., s. 473-481.

Johnson Phillip E., Reason in the Balance: The Case Against Naturalism in Science, Law \& Education, InterVarsity Press, Downers Grove 1995.

Johnson Phillip E., „Reguły rozumowania darwinizmu”, przeł. Kazimierz Jodkowski, w: JoDKOwsKi, Metodologiczne aspekty..., s. 460-472.

JoHnson Phillip E., Wielka metafizyczna opowieść nauki (z posłowiem Kazimierza Jodkowskiego), przeł. Piotr Bylica, Archiwum Na Początku..., z. 13, Polskie Towarzystwo Kreacjonistyczne, Warszawa 2003.

KAziBuT Radosław, „Filozoficzna gramatyka praktyki laboratoryjnej Hasoka Changa a epistemiczny układ odniesienia Roberta Boyle'a", w: Godek, Musią i Woszczak (red.), X Polski Zjazd Filozoficzny..., s. 419-420.

Kilian Krzysztof J., Poglądy filozoficzne Paula K. Feyerabenda. Część I. Program metodologiczny, Oficyna Wydawnicza Uniwersytetu Zielonogórskiego, Zielona Góra 2014.

Kilian Krzysztof J., „Wzrost wiedzy a zasada tolerancji”, w: Michalczenia, Mizińska i Ossowska (red.), Poszukiwania filozoficzne. T. I..., s. 155-173.

KoJonen Erkki V.R., „Methodological Naturalism and the Truth Seeking Objection”, International Journal for Philosophy of Religion 2016, vol. 79, no. 3, s. 1-26, http://tiny.pl/gkf xk (18.01.2018).

Konstańczak Stefan i Turowski Tomasz (red.), Filozofia jako mądrość bycia. Profesorowi Krzysztofowi Kaszyńskiemu w darze z okazji 70. urodzin, Oficyna Wydawnicza Uniwersytetu Zielonogórskiego, Zielona Góra 2009.

Kopeć Radosław i CHoJecki Paweł, „Wywiad z prof. Jodkowskim”, Idź Pod Prąd 2007, nr 11 (40), s. 8 i 11, www.nauka-a-religia.uz.zgora.pl/images/Przedruki/Kopec.Chojecki_Wy wiad.z.prof.Jodkowskim.pdf (15.02.2018).

Krause Tomasz, „Filozoficzne aspekty tzw. «afery Kansas»”, Filozoficzne Aspekty Genezy 2004 , t. 1, s. 143-224, www.nauka-a-religia.uz.zgora.pl/images/FAG/2004.t.1/art.08.pdf (03.02.2018).

KuHN Thomas S., Struktura rewolucji naukowych, przeł. Helena Ostromęcka i Justyna Nowotniak, Aletheia, Warszawa 2001.

KWAŚNIEWSKI Jacek, „Nauka a religia. Historiografia problemu. Ewolucja poglądów na temat historycznych związków religii i nauki”, Zagadnienia Filozoficzne w Nauce 2011, nr XLIX, s. 149-187, http://tiny.pl/gkdvk (12.02.2018).

Lakatos Imre and Feyerabend Paul K., For and Against Method: Including Lakatos's Lectures on Scientific Method and the Lakatos-Feyerabend Correspondence, ed. Matteo Motterlini, The University of Chicago Press, Chicago — London 1999. 
Larmer Robert A., „Is Methodological Naturalism Question-Begging?”, Philosophia Christi 2003, vol. 5, no. 1, s. 113-130, www.epsociety.org/userfiles/art-Larmer\%20(Metho dologicalNaturalismQuestion-Begging).pdf (01.01.2018).

LATAWIEC Anna i BugaJAK Grzegorz (red.), Filozoficzne i naukowo-przyrodnicze elementy obrazu świata 7, Wydawnictwo Uniwersytetu Kardynała Stefana Wyszyńskiego, Warszawa 2008.

LAUDAN Larry, „Zgon kryterium demarkacji”, przeł. Artur Koterski, w: MusZYŃSKi (red.), Z badań nad prawdą, nauką i poznaniem..., s. 63-79.

LeMaster James C., „The Relationship of Bacon, Teleology, and Analogy to the Doctrine of Methodological Naturalism", w: Bartlett and Holloway (eds.), Naturalism and Its Alternatives..., s. 67-89.

LeMaster James C., „Związek między Baconem, teleologią i analogią a doktryną naturalizmu metodologicznego", przeł. Dariusz Sagan, Filozoficzne Aspekty Genezy 2017, t. 14, s. 99-133, http://tiny.pl/gkfx2 (10.03.2018).

LESZCZYŃSKi Damian (red.), Ewolucja, filozofia, religia, Lectiones \& Acroases Philosophicae 2010, vol. III.

LÓPEZ Mario A., „Projekt jako kryterium demarkacji”, przeł. Dariusz Sagan, Filozoficzne Aspekty Genezy 2016, t. 13, s. 75-100, www.nauka-a-religia.uz.zgora.pl/images/FAG/2016. t.13/art.12.pdf (12.01.2018).

Luskin Casey, „Teoria inteligentnego projektu nie wypowiada religijnych twierdzeń o sferze nadnaturalnej”, przeł. Izabela Janus, Filozoficzne Aspekty Genezy 2009/2010, t. 6/7, s. 93-116, http://tiny.pl/xhnlg (25.01.2018).

Lyell Charles, Principles of Geology or, the Modern Changes of the Earth and its Inhabitants Considered as Illustrative of Geology, D. Appleton \& Co., New York 1854, https://archive.org/details/principlesofgeol00lyelrich (19.01.2018).

ŁASTOWSKI Krzysztof, „Kilka uwag o sporze ewolucjonizmu $z$ «naukowym kreacjonizmem» w związku z książką K. Jodkowskiego Metodologiczne aspekty kontrowersji ewolucjonizm-kreacjonizm", Przegląd Filozoficzny - Nowa Seria 2001, R. X, nr 1 (37), s. 229-240, www.nauka-a-religia.uz.zgora.pl/images/Przedruki/Lastowski_Kilka.uwag.o.sp orze.ewolucjonizmu.z.naukowym.kreacjonizmem.pdf (08.02.2018).

MALEC Grzegorz, „Erozja teizmu Darwina, czyli wpływ podróży na okręcie HMS Beagle na poglądy teologiczne angielskiego przyrodnika", w: BAŁĘKOWSKI i MACIĄG (red.), Wybrane zagadnienia $\mathbf{z}$ filozofii języka i religii..., s. 110-120, www.nauka-a-religia.uz.zgora.pl/ images/Przedruki/Malec_Erozja.teizmu.Darwina.pdf(08.02.2018).

MALEC Grzegorz, „Naturalizm metodologiczny w sporze ewolucjonizmu z kreacjonizmem w świetle poglądów Paula K. Feyerabenda”, Filozoficzne Aspekty Genezy 2012, t. 9, s. 131154, http://www.nauka-a-religia.uz.zgora.pl/images/FAG/2012.t.9/art.12.pdf (20.01.2018). 
Malec Grzegorz, „«Wzniosły jest pogląd, że Stwórca...», czyli łapówka Darwina dla chrześcijan", Filozoficzne Aspekty Genezy 2014, t. 11, s. 187-204, http://www.nauka-a-reli gia.uz.zgora.pl/images/FAG/2014.t.11/art.09.pdf (17.01.2018).

McMuluin Ernan, „Odmiany naturalizmu metodologicznego”, przeł. Ewelina Topolska, Filozoficzne Aspekty Genezy 2012, t. 9, s. 109-129, http://www.nauka-a-religia.uz.zgora.pl/ images/FAG/2012.t.9/art.02.pdf (20.01.2018).

Meyer Stephen C., „Demarkacja nauki i religii”, przeł. Joanna Popek, Filozoficzne Aspekty Genezy 2009/2010, t. 6/7, s. 177-196, http://www.nauka-a-religia.uz.zgora.pl/images/FAG/ 2009-2010.t.6-7/art.11.pdf (26.01.2018).

Meyer Stephen C., „Scientific Tenets of Faith”, Journal of the American Scientific Affiliation 1986, vol. 38, no. 1, http://www.arn.org/docs/meyer/sm_scientifictenets.htm (13.02. 2018).

Michalczenia Jakub, Mizińska Jadwiga i Ossowska Katarzyna (red.), Poszukiwania filozoficzne. Tom I: Nauka, Prawda. Panu Profesorowi Józefowi Dębowskiemu w darze, Instytut Filozofii Uniwersytetu Warmińsko-Mazurskiego w Olsztynie, Olsztyn 2014.

Miller Keith B., „The Misguided Attack on Methodological Naturalism”, w: Schneiderman and Allmon (eds.), For the Rock Record..., s. 117-140.

Moreland James Porter and Craig William Lane, Philosophical Foundations for a Christian Worldview, InterVarsity Press, Downers Grove 2003.

Morris Henry M., „Evolution Is Religion - Not Science”, Acts \& Facts 2001, vol. 30, no. 2, https://www.icr.org/article/455 (17.02.2018).

Morris Henry M., Scientific Creationism, Creation-Life Publishers, San Diego 1974.

Murphy Nancey, „Phillip Johnson on Trial: A Critique of His Critique of Darwin”, Perspectives on Science and Christian Faith 1993, vol. 45, no. 1, s. 26-36, http://www.asa3. org/ASA/PSCF/1993/PSCF3-93Murphy.html (17.02.2018).

MusZYŃSKi Zbysław (red.), Z badań nad prawdą, nauką i poznaniem, Realizm. Racjonalność. Relatywizm, t. 31, Wydawnictwo UMCS, Lublin 1998.

Nagel Thomas, „Public Education and Intelligent Design”, Philosophy \& Public Affairs 2008, vol. 36, no. 2, s. 187-205.

Nelson Paul, „Methodological Naturalism: A Rule That No One Needs or Obeys”, Evolution News and Science Today 22 September 2014, https://evolutionnews.org/2014/09/metho dological_1/(02.01.2018).

NowAK Grzegorz, „Książka filozofa o sporze między ewolucjonistami i kreacjonistami”, Filozofia Nauki 2001, t. 9, nr 2, s. 161-168.

O’ConNor Robert C., „Nauka przed sądem: analiza racjonalności naturalizmu metodologicznego", przeł. Joanna Popek i Grzegorz Rogula, Filozoficzne Aspekty Genezy 2014, 
t. 11, s. 95-131, http://www.nauka-a-religia.uz.zgora.pl/images/FAG/2014.t.11/art.04.pdf (16.01.2018)

O'Connor Robert C., ,Science on Trial: Exploring the Rationality of Methodological Naturalism", Perspectives on Science and Christian Faith 1994, vol. 49, no. 1, s. 15-31, http:// www.asa3.org/ASA/PSCF/1997/PSCF3-97OConnor.html (16.01.2018).

OldRoyd David R., Darwinian Impacts: An Introduction to the Darwinian Revolution, Humanities Press, Atlantic Highlands, New Jersey 1980.

OrR H. Allen, „Ponownie darwinizm kontra inteligentny projekt”, przeł. Dariusz Sagan, Filozoficzne Aspekty Genezy 2004, t. 1, s. 33-48, www.nauka-a-religia.uz.zgora.pl/images/ FAG/2004.t.1/art.05.pdf(02.02.2018).

PENNOCK Robert T., „Bóg w lukach wiedzy: argument z niewiedzy i ograniczenia naturalizmu metodologicznego", przeł. Dariusz Sagan, Filozoficzne Aspekty Genezy 2012, t. 9, s. 155-185, http://www.nauka-a-religia.uz.zgora.pl/images/FAG/2012.t.9/art.04.pdf (20.01. 2018).

PenNock Robert T., „Creationism and Intelligent Design”, Annual Review of Genomics and Human Genetics 2003, vol. 4, s. 143-163, http://bio.classes.ucsc.edu/bio175/Other/Pennock 2003.pdf (03.01.2018).

Perakh Mark, „Nieredukowalna sprzeczność”, przeł. Dariusz Sagan, Filozoficzne Aspekty Genezy 2004, t. 1, s. 71-113, www.nauka-a-religia.uz.zgora.pl/images/FAG/2004.t.1/art.04. pdf (03.02.2018).

PietrZaK Zbigniew (red.), Albert Einstein i rewolucja relatywistyczna, Lectiones \& Acroases Philosophicae 2016, t. IX, nr 1.

PietrZak Zbigniew (red.), Granice nauki, Lectiones \& Acroases Philosophicae 2013, t. VI, nr 1.

Piotrowski Robert, „Kulturowe a filozoficzne tło neokreacjonizmu amerykańskiego”, w: JODKOWSKI (red.), Teoria inteligentnego projektu..., s. 25-50.

Plantinga Alvin, „Naturalizm metodologiczny?”, przeł. Radosław Plato, Filozoficzne Aspekty Genezy 2014, t. 11, s. 37-93, http://www.nauka-a-religia.uz.zgora.pl/images/FAG/ 2014.t.11/art.03.pdf (15.01.2018).

Poe Harry Lee i Mүтүк Chelsea Rose, „Od metody naukowej do naturalizmu metodologicznego. Ewolucja idei”, przeł. Bartosz Błaszczak, Gerard Dmuch, Ewa Komorowska, Iwona Kumiszcze, Izabela Obłaczyńska, Katarzyna Piłka, Radosław Plato, Marika Poprawska, Dariusz Sagan, Karolina Stencel, Katarzyna Szot i Piotr Wróblewski, Filozoficzne Aspekty Genezy 2011, t. 8, s. 137-151, http://www.nauka-a-religia.uz.zgora.pl/images/FAG/ 2011.t.8/art.09.pdf (24.01.2018). 
Porpora Douglas V., „Methodological Atheism, Methodological Agnosticism and Religious Experience", Journal for the Theory of Social Behaviour 2006, vol. 36, no. 1, s. 57-75, http://tiny.pl/gkfx8 (20.01.2018).

Provine William B., „Projekt? Tak! Ale czy inteligentny?”, przeł. Sławomir Piechaczek, Filozoficzne Aspekty Genezy 2005/2006, t. 2/3, s. 217-237, www.nauka-a-religia.uz.zgora.pl/ images/FAG/2005-2006.t.2-3/art.10.pdf(01.02.2018).

RATzSCH Del, „Teologia naturalna, naturalizm metodologiczny i «żółwie do samego dołu»”, przeł. Dariusz Sagan, Filozoficzne Aspekty Genezy 2016, t. 13, s. 119-152, http://www.nau ka-a-religia.uz.zgora.pl/images/FAG/2016.t.13/art.03.pdf(13.01.2018).

RENNIE John, „15 odpowiedzi na nonsensowne tezy kreacjonistów”, przeł. Karol Sabath, Świat Nauki 2002, nr 9, s. 66-72, http://creationism.org.pl/groups/ptkrmember/spor/pl/Ren nie,\%2015\%20odpowiedzi.pdf/view (13.02.2018).

Roskal Zenon E., „Eksperyment MacDougalla w epistemicznym układzie odniesienia naturalizmu”, w: Bylica, Kilian, Piotrowski i Sagan (red.), Filozofia - nauka - religia..., s. 165-172, www.nauka-a-religia.uz.zgora.pl/images/Przedruki/Roskal_Eksperyment.Mac Dougalla.pdf (06.02.2018).

RowiŃski Tomasz, „Dlaczego warto nauczać «dwóch stron»? O edukacji, ewolucji i teorii inteligentnego projektu. Rozmowa z o. Michałem Chaberkiem, dominikaninem, doktorem teologii fundamentalnej, autorem książki Stworzenie czy ewolucja? Dylemat katolika", Christianitas 2014, nr 58, s. 70-82, http://christianitas.org/news/dlaczego-warto-nauczacdwoch-stron-o-edukacji-ewolucji-i-teorii-inteligentnego-projektu (23.01.2018).

RusE Michael, „Darwin's Debt to Philosophy: An Examination of the Influence of the Philosophical Ideas of John F.W. Herschel and William Whewell on The Development of Charles Darwin's Theory of Evolution", Studies in History and Philosophy of Science Part A 1975, vol. 6, no. 2 s. 159-181, http://tiny.pl/gkfhx (08.02.2018).

Ruse Michael, „The Argument from Design: A Brief History”, w: Dembsк and Ruse (eds.), Debating Design..., s. 13-31, https://www.researchgate.net/publication/285439477_The Argument_from_Design_A_Brief_History (19.01.2018).

RYLAND Mark, „«Teoria inteligentnego projektu» podważa teorię ewolucji. Już sama złożoność stworzenia świadczy o działaniu siły wyższej. Darwinizm? Nie ma szans. Wywiad z Michaelem J. Behe'em dla Our Sunday Visitor', przeł. Dariusz Sagan, Na Początku... 2004, nr 11-12A (187-188), s. 414-420, www.nauka-a-religia.uz.zgora.pl/images/Przedru ki/Ryland_Teoria.ID.podwaza.teorie.ewolucji.pdf (22.01.2018).

SAGAN Dariusz, „Filtr eksplanacyjny: wykrywanie inteligentnego projektu na gruncie nauk przyrodniczych", Roczniki Filozoficzne 2009, t. LVII, nr 1, s. 157-193, www.nauka-a-reli gia.uz.zgora.pl/images/Przedruki/Sagan_Filtr.eksplanacyjny.pdf (21.01.2018). 
SAGan Dariusz, „Michaela Behe’ego koncepcja nieredukowalnej złożoności”, Na Począt$k u \ldots .2003$, nr 11-12 (174-175), s. 402-417, www.nauka-a-religia.uz.zgora.pl/images/Przed ruki/Sagan_Michaela.Beheego.koncepcja.IC.pdf (02.02.2018).

SAGan Dariusz, „Molekularny «zegar Paleya» a darwinowska ewolucja”, Ruch Filozoficzny 2005, t. LXII, nr 2, s. 289-304, http://tiny.pl/xh8tk (21.01.2018).

SAGAN Dariusz, „Naturalizm metodologiczny — konieczny warunek naukowości?”, Roczniki Filozoficzne 2013, t. LXI, nr 1, s. 73-91, http://tiny.pl/q33sb (04.02.2018).

SAGAN Dariusz, „Nieredukowalna złożoność jako świadectwo inteligentnego projektu”, Fronda 2012, nr 63, s. 49-65, http://tiny.pl/gkfxq (21.01.2018).

SAGAN Dariusz, „Odpowiedź na uwagi polemiczne ks. dra Marka Słomki do mojego artykułu o filtrze eksplanacyjnym", Roczniki Filozoficzne 2009, t. LVII, nr 1, s. 345-349, http:// tiny.pl/xhzm6 (21.01.2018).

SAGAN Dariusz, „Retoryczna historia Ruchu Inteligentnego Projektu”, Diametros 2005, nr 4, s. 76-85, www.nauka-a-religia.uz.zgora.pl/images/Przedruki/Sagan_Retoryczna.historia. Ruchu.ID.pdf (21.01.2018).

SAGAN Dariusz, „Spór o możliwość wykrywania projektu w naukach przyrodniczych”, Scientia et Fides 2015, t. 3, nr 1, s. 87-113, www.nauka-a-religia.uz.zgora.pl/images/Przed ruki/Sagan_Spor.o.mozliwosc.wykrywania.projektu.pdf (09.02.2018).

SAGAN Dariusz, Spór o nieredukowalną złożoność układów biochemicznych, Biblioteka Filozoficznych Aspektów Genezy, t. 5, Wydawnictwo MEGAS, Warszawa 2008, www.nau ka-a-religia.uz.zgora.pl/images/Przedruki/Sagan_Spor.o.nieredukowalna.zlozonosc.pdf (23. 01.2018).

SAGAN Dariusz, „Teleologiczne wyjaśnienie nieredukowalnej złożoności układów biochemicznych", Roczniki Filozoficzne 2006, t. LIV, nr 1, s. 139-160, http://tiny.pl/gkfxs (04.02. 2018).

SAGAN Dariusz, „Teoria inteligentnego projektu — argumenty za i przeciw”, w: JANECZEK, Starościc, DÅßeK i Herda (red.), Filozofia przyrody..., s. 335-383, www.nauka-a-religia. uz.zgora.pl/images/Przedruki/Sagan_Teoria.ID.argumenty.za.i.przeciw.pdf (10.02.2018).

SAGan Dariusz, „Teoria inteligentnego projektu a ewolucjonizm”, Kwartalnik Filozoficzny 2013, t. XLI, z. 2, s. 75-96, www.nauka-a-religia.uz.zgora.pl/images/Przedruki/Sagan_Teo ria.ID.a.ewolucjonizm.pdf (17.02.2018).

SAGan Dariusz, „Teoria inteligentnego projektu a kreacjonizm”, Kwartalnik Filozoficzny 2015, t. XLIII, z. 2, s. 131-150, www.nauka-a-religia.uz.zgora.pl/images/Przedruki/Sagan_ Teoria.ID.a.kreacjonizm.pdf (09.02.2018).

SAGAN Dariusz, „Wspólnota pochodzenia jako argument w sporze darwinizm-teoria inteligentnego projektu", Diametros 2013, nr 37, s. 127-145, www.nauka-a-religia.uz.zgora.pl/ images/Przedruki/Sagan_Wspolnota.pochodzenia.pdf (17.02.2018). 
SAGAN Dariusz, „Wyjaśnianie za pomocą praw przyrody jako warunek naukowości w sporze o ewolucję i inteligentny projekt", Studia Philosophiae Christianae 2013, t. 49, nr 1, s. 93-116, www.nauka-a-religia.uz.zgora.pl/images/Przedruki/Sagan_Wyjasnianie.za.pomo ca.praw.przyrody.pdf (10.02.2018).

SAGAN Dariusz, „Zdolność przewidywania jako warunek naukowości w sporze o ewolucję i inteligentny projekt", Zagadnienia Naukoznawstwa 2012, nr 4 (194), s. 269-286, http://ti ny.pl/q3367 (17.02.2018).

Schiller Ferdinand C.S., „Darwinism and Design”, w: Schiller, Humanism..., s. 128-156, http://tiny.pl/gkfx6 (22.01.2018).

Schiller Ferdinand C.S., Humanism: Philosophical Essays, The Macmillan Company, London and New York 1903.

Schneiderman Jill S. and Allmon Warren D. (eds.), For the Rock Record: Geologists on Intelligent Design, University of California Press, Berkeley, Los Angeles, London 2009.

Scotт Eugenie C., Evolution vs. Creationism. An Introduction. Second Edition, Greenwood Press, Westport, Connecticut, London 2009.

Shormann David E., ,, The Revolution of Creationism”, Creation Matters 2012, vol. 17, no. 6, s. 1-3, http://tiny.pl/gnlgn (20.02.2018).

Smart Joshua A., „O zastosowaniu pojęcia nieredukowalnej złożoności”, Na Początku... 2004, nr 11-12A (187-188), s. 421-447, http://tiny.pl/xh4f4 (12.02.2018).

SNOKE David, „Biologia systemowa jako paradygmat badawczy teorii inteligentnego projektu”, przeł. Dariusz Sagan, Filozoficzne Aspekty Genezy 2015, t. 12, s. 255-285, http:// www.nauka-a-religia.uz.zgora.pl/images/FAG/2015.t.12/art.03.pdf (15.01.2018).

SoBER Elliott, „Teoria inteligentnego projektu a nadnaturalizm - o tezie, że projektantem może być Bóg lub istoty pozaziemskie”, przeł. Sławomir Piechaczek, Filozoficzne Aspekty Genezy 2007/2008, t. 6/7, s. 21-39, http://www.nauka-a-religia.uz.zgora.pl/images/FAG/ 2007-2008.t.4-5/art.06.pdf (27.01.2018).

Stilwell Phil, „The Status of Methodological Naturalism as Justified by Precedent”, Studies in Liberal Arts and Sciences 2009, no. 41, s. 229-247.

Thнхтом Charles, „Nowy argument z projektu”, przeł. Izabela Janus, Filozoficzne Aspekty Genezy 2011, t. 8, s. 155-177, http://www.nauka-a-religia.uz.zgora.pl/images/FAG/2011.t.8/ art.02.pdf (24.01.2018).

„Top Questions and Answers on Intelligent Design”, 8 September 2005, http://www.disco very.org/a/2348 (20.01.2018).

van Der MeEr Jitse M., „Przekonania towarzyszące, ideologia i nauka”, przeł. Dariusz Sagan, Filozoficzne Aspekty Genezy 2016, t. 13, s. 153-194, http://www.nauka-a-religia.uz. zgora.pl/images/FAG/2016.t.13/art.04.pdf(13.0.2018). 
Vihalemm Rein, „The Kuhn-Loss Thesis and the Case of Phlogiston Theory”, Science Studies 2000 , vol. 13 , no. 1 , s. 68-78.

WaLKeR Tas, ,Jak obiektywni są naukowcy?”, przeł. Katarzyna Gieremek, Na Poczatku... 2000, nr 3-4 (127-128), s. 74-76, https://creationism.org.pl/artykuly/TWalker (02.02.2018).

Willma Adam, „Przyroda, Bóg, nauka. Rozmowa z profesorem Kazimierzem Jodkowskim”, Gazeta Pomorska 2 listopada 2006, s. 7, www.nauka-a-religia.uz.zgora.pl/images/ Przedruki/Jodkowski_Przyroda.Bog.nauka.pdf (18.01.2018).

WITT Jonathan, „Zarys historii powstania naukowej teorii inteligentnego projektu”, przeł. Dariusz Sagan, Na Poczatku ... 2005, nr 9-10 (198-199), s. 352-362, www.nauka-a-religia. uz.zgora.pl/images/Przedruki/Witt_Historia.powstania.ID.pdf (22.01.2018).

WOODWARD Thomas, „Istota sporu darwinizmu z teorią inteligentnego projektu: przyrodnicza symfonia makroewolucji”, przeł. Dariusz Sagan, Filozoficzne Aspekty Genezy 2007/ 2008, t. 6/7, s. 7-20, http://www.nauka-a-religia.uz.zgora.pl/images/FAG/2007-2008.t.4-5/ art.01.pdf (27.01.2018).

Wóscik Bogusław, „Czy teoria inteligentnego projektu i neodarwinizm mogą być komplementarne?", Zagadnienia Filozoficzne w Nauce 2007, nr XLI, s. 28-45, http://tiny.pl/gkg4g (21.01.2018).

ZавоњотNY Andrzej, „Naturalizm metodologiczny w nauce - dylemat teisty”, Filozoficzne Aspekty Genezy 2016, t. 13, s. 25-48, http://www.nauka-a-religia.uz.zgora.pl/images/FAG/ 2016.t.13/art.09.pdf (24.01.2018).

Zon Józef (red.), Pogranicza nauki. Protonauka - paranauka - pseudonauka, Wydawnictwo KUL, Lublin 2009.

ZyвeRTowicz Andrzej z zespołem, Samobójstwo Oświecenia?, Wydawnictwo Kasper, Kraków 2015.

\section{Geneza idei epistemicznych ukladów odniesienia i ich odmiany}

\section{Streszczenie}

Nazwa „epistemiczny układ odniesienia” została wprowadzona przez Kazimierza Jodkowskiego w 2004 roku i jest efektem jego uprzednich analiz sporu ewolucjonizmu z kreacjonizmem.

Epistemiczne układy odniesienia to niewielkie, dwu- lub trzyelementowe zbiory najogólniejszych, historycznie zmiennych założeń, które określają konieczne warunki uprawiania nauki. Współcześnie, z dwoma, bazującymi na naturalizmie metodologicznym, epistemicznymi układami odniesienia, rywalizują epistemiczne układy odniesienia nadnaturalizmu i artyficjalizmu. 
Epistemiczny układ odniesienia naturalizmu antynadnaturalistycznego to nakaz przyjmowania jedynie naturalistycznych wyjaśnień dla faktów i procesów, któremu towarzyszy zakaz przyjmowania wyjaśnień antynaturalistycznych, pojmowanych jako zakaz powoływania się na przyczyny nadnaturalne.

Epistemiczny układ odniesienia nadnaturalizmu to nakaz dopuszczania w wyjaśnianiu zjawisk przyrodniczych obok przyczyn naturalnych również wyjaśnień odwołujących się do przyczyn nadnaturalnych — interwencji bytu nadprzyrodzonego, czyli Boga.

Epistemiczny układ odniesienia naturalizmu antyartyficjalistycznego to nakaz przyjmowania jedynie naturalistycznych wyjaśnień dla faktów i procesów, któremu towarzyszy zakaz przyjmowania wyjaśnień antynaturalistycznych, pojmowanych jako zakaz powoływania się na przyczyny sztuczne (inteligentne, celowe).

Epistemiczny układ odniesienia artyficjalizmu to nakaz dopuszczania w badaniach naukowych obok przyczyn naturalnych również przyczyn sztucznych, inteligentnych.

Slowa kluczowe: Kazimierz Jodkowski, epistemiczny układ odniesienia, twarde jądro, naturalizm metodologiczny, nadnaturalizm, artyficjalizm, teoria inteligentnego projektu, kreacjonizm, ewolucjonizm, zasada inkluzji, zasada ekskluzji.

\section{The Origin of the Idea of Epistemic Frameworks, and Their Varieties}

\section{Summary}

The term "epistemic framework" was coined by Kazimierz Jodkowski in 2004. That expression, together with the notion of epistemic frameworks, is the outcome of his prior analyses of the evolution-creation controversy.

Epistemic frameworks are small, two- or three-element sets of the most general, historically changeable assumptions. These assumptions determine sine qua non conditions of scientific practice. Nowadays, two epistemic frameworks based on methodological naturalism are in competition with the epistemic frameworks of supernaturalism and artificialism.

The epistemic framework of antisupernaturalistic naturalism adheres to the precept of accepting only naturalistic explanations for facts and processes. That precept is correlated with a proscription on accepting antinaturalistic explanations, construed in turn as a proscription on referring to supernatural causes.

The epistemic framework of supernaturalism follows the precept of accepting not only naturalistic explanations for facts and processes, but also supernaturalistic ones - interventions by a divine being, namely God.

The epistemic framework of anti-artificialistic naturalism observes the precept of accepting only naturalistic explanations for facts and processes. That precept is correlated with a proscription on accepting antinaturalistic explanations, construed in turn as a proscription on referring to artificial (intelligent) causes. 
The epistemic framework of artificialism embraces the precept of accepting, in the context of scientific research, not only natural causes, but artificial (intelligent) ones as well.

Keywords: Kazimierz Jodkowski, epistemic framework, hard core, methodological naturalism, supernaturalism, artificialism, intelligent design, creationism, theory of evolution, principle of inclusivity, principle of exclusivity. 